University of Louisville

ThinkIR: The University of Louisville's Institutional Repository

$10-1944$

\title{
A study of the history of adult elementary and secondary education and possibilities for future service in Louisville, Kentucky.
}

Flora L. Morris

University of Louisville

Follow this and additional works at: https://ir.library.louisville.edu/etd

Part of the Education Commons

\section{Recommended Citation}

Morris, Flora L., "A study of the history of adult elementary and secondary education and possibilities for future service in Louisville, Kentucky." (1944). Electronic Theses and Dissertations. Paper 2012.

https://doi.org/10.18297/etd/2012

This Master's Thesis is brought to you for free and open access by ThinkIR: The University of Louisville's Institutional Repository. It has been accepted for inclusion in Electronic Theses and Dissertations by an authorized administrator of ThinkIR: The University of Louisville's Institutional Repository. This title appears here courtesy of the author, who has retained all other copyrights. For more information, please contact thinkir@louisville.edu. 


\title{
A STUDY OF THE HISTORY OF \\ ADULT ELFMEITARY AND SECONDARY EDUCATIOI ANID \\ POSSIBIUITIES FOR FUTURE SERVICE \\ III \\ LOUISVILIR, KEWTUCKI
}

\author{
A Thesis \\ Presented to \\ the Faculty of the pepartment of Education \\ University of Iouigville
}

In Partial Fulfillment

of the Requiremente for the Degree

Naster of Arts

\author{
by \\ Flora 1. Morris
}

September 1944 
This PDF document is a scanned copy of a paper manuscript housed in the University of Louisville (UofL) Libraries. The quality of this reproduction is greatly dependent upon the condition of the original paper copy. Indistinct print and poor quality illustrations are a direct reflection of the quality of materials that are available for scanning. The UofL Libraries greatly appreciates any better copies that can be made available for replacement scans. 
MAN OF STUDET:

Flora L. Morris

TITLE OF THESIS: A STUDY OF THE HISTORY OF
ADULF ELFIMITARY AUD SECOMDARY EDUCATIOM AID
POSSIBILITIES FOR FUTURE SERVICE III

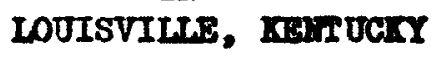

APPROVED BY READIHG CONITTES COAPOSED OF TER

FOLTOWIMG MEMBERs:

Hilda Threlkeld

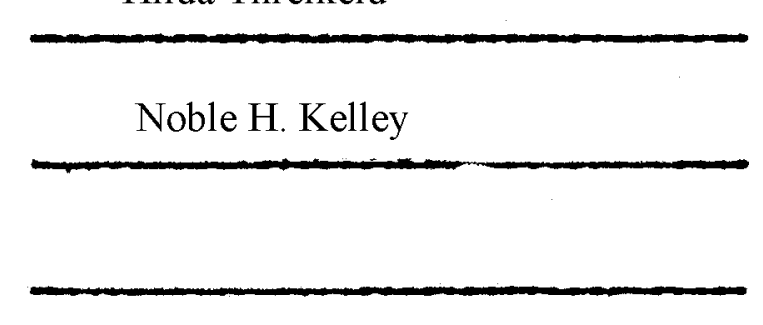

WAR OF DIRETOR:

J. J. Oppenheimer

Darm: 0 ct, $14,1944$. 
TABLE OF CONTENTS

PAGE

List of Tables $\ldots \ldots \ldots \ldots \ldots \ldots \ldots \ldots \ldots \ldots \ldots \ldots \ldots \ldots \ldots \ldots$. 111

PREFACE $\ldots \ldots \ldots \ldots \ldots \ldots \ldots \ldots \ldots \ldots \ldots \ldots \ldots \ldots \ldots \ldots \ldots \ldots \ldots \ldots$ iv

ACKTOWL BDGEMENTS $\ldots \ldots \ldots \ldots \ldots \ldots \ldots \ldots \ldots \ldots \ldots \ldots \ldots \ldots$

CHAPTER

I BACKGROUNDS FOR THE STUDY OF ADUT EDUCATION

Definition of Adult Education ............... l

Significance of Thorndike 's Findings ...........

American Association of Adult Education ......... 3

Federal Government Program of Adult Education .....4 4

Purpose, Mmpasis, Scope, Limitations .......... 7

Phllosophy of Adult Education .............. 8

II ELEMENTARY AND SECONDARY NIGHT SCHOOLS

History of Night Schools in Louisville ......... 12

First Night Schools in Louisville ............ 12

First Nlght School for Working Men ............ 18

Federal Program of Adult Education .............21

Vocational Classes .......................28

Orig in and Derelopment of Adult Migh School ...... 30

Types of Work offered ..................... 39

School Moved to Honsarrat School Building ....... 42

Progress at Monsarrat ......................44

Summary of the Work of Adult High School ........ 50 
TABLE OF CONTENTS

(continued)

CHAPTER

PAGE

II (Continued)

Closing of MPA Adult Ecucation Program ............. 53

Organization of Vight High School at ihrens ........ 58

III ADULT BUUCATION UNDER FUBLIC SCHOOL SYSTEMS OF OPHER CITIES Attitudes of Public school Administrators ........... 63

Opportunity school at venver, Colorado ............. 64

Adult Education Center, jan Jose, California ......... 71

The Public ivening schools of Philadelphia .......... 75

IV POSEIBILITIES FOR SERVICT TO AUULPS IN LOUISVILLE

Counselling and Retraining Program .............. 80

General bducation for Adults, any Grade ............ 81

Classes in Civic anó social Understandines ......... 82

Standard Iigh school for didults ................ 84

Vocational Saucation for faults ................ 86

Recreational opportunities ................... 90

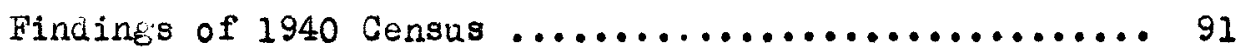

$\checkmark$ SUIMARY all CONCLUSTONS $\ldots \ldots \ldots \ldots \ldots \ldots \ldots \ldots \ldots \ldots \ldots . . . \ldots 3$

APPWNDIX $\ldots \ldots \ldots \ldots \ldots \ldots \ldots \ldots \ldots \ldots \ldots \ldots \ldots \ldots \ldots \ldots \ldots \ldots$

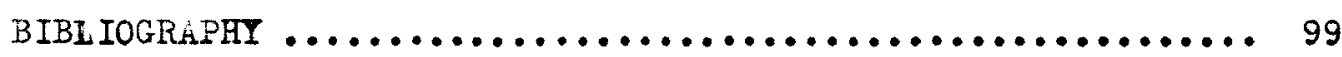




\section{LIST OF TABLES}

PAGE

TABLE I Night Schools in Louisville, 1875-1876........ 12

TABLE II Night Schools in Louisville, $1887 \ldots \ldots \ldots \ldots \ldots . .14$

TABLE III Night Schools in Louisville, 1928-1931 ....... 20

TABLE IV Characteristics of Student Body, Ldult Ecucation High School, 1937-1938 ...................... 39

TABLE V Adult Education High School Enrollment by Classes, $1942-1943$...................... 51

TABLE VI Summary of Finrollment in Louisville Adult Education High School, 1936-1943 ............... 50

TABLE VII Findings of Sixteenth Census of the United States 1940 


\section{PREFACE}

This study was inspired by a statement in the Louisville Public School Survey, 1943, in which ir. George A. Works said,

Programs of adult education are exceedingly important in the modern community. The nature of modern life and the demands for continuous oducation and training sugrest the need for school service in this area. Following the war, the demand will undoubtediy be very great. Loulsville would do well to assign definite staff time for development of basic plans in this area.

The witer was connected with the Works Progress Administration Adult Education Program as teacher from 1935 to 1937, and as principal of the Adult Hight High School from 1937 until it closed in June, 1943. She was assistant principal of the Adult Jight High School at Ahrens Trade School 1943-1944. It is with pleasure that she has undertaken this study, and it is her one hope that some small benefit to the people of Louisville will accrue from its pages; and that a greater insight into the needs and satisfactions of adults, and the ways and means of obtaining these through education may be her share in the results of this study.

The purpose of the study sholl be to find out more about adult education; its growth and phllosophy; what has been done ander public schools systems in other cities, and what can be done to improve the educational opportianities offerea adults in Louievilie. 
It will cover general eucation of elementary and secondary level for white adults only, and will leave the programs now conducted by the University of Louisville, the Negro N1ght School, and the private osencles for other studies.

Through records of what has been done in louisville; studies of programs under public school systems in other cities; interviews with persons interested in education; and the phllosophy of adult education, -- the writer will try to show the background for a program of adult education in Louisville today; the growth of interest; impetus gained through the Federal Government Program; the need for the work in Louisville; and possibllities for extending the opportunities offered adults in Louisille.

The sources of date used are publications of the American Association of Adult Education; books and articles contributed by leaders in this field of education; annual reports and records of the Loufaville Board of Education; materials furnished by the State Director of WPA Bducation; Information gained by interview; newspaper articlea; and data which the writer has gathereo during her connection with the adult education program.

The study will try to show possibilities for greater service through a program of education for adults in the elementary and secondary school levels. 


\section{ACKMOWLEDGMENTS}

The writer is deeply indebted to Dr. J.J. Oppenhe imer, Head of the Department of Bducation, for his valuable instruotion and patient guidance. Appreoiation is due President E. W. Jacobsen, who gave graclous sssistance in the form of susgestions and materials. Hefs Kathryn Kreat, secretary to the Superintendent of the Louisville Public Schools, gave kindly ald to the writer in locating data through the Annual School Board Reports.

Especially is the writer grateful to Prof. F.W. Stamm, Director of the Division of Adult Education of the University of Louigrille, for h1. aselatance and encouragement.

Lastly, she wisher to acknowledge the raluable ald given by fre Linsey F. Allen, former Director of WPA Education in Kentucky. Without his kindly ald, his materials, and his interest, this study could not have been completed. 


\section{CHAPTER I}

BACKGROUNDS FOR THE STUDY OF AN ADULT PROGRAM

Programs of adult education are based on the recognition of the fact that the individual does not obtain in a few years of schoolIng all the intellectual equipment needed for a successful 1 ife, and that more or less continuous efforts must be made toward a conscious process of learning. James Truslow Adams, in his book Frontiers of American Culture, said:

Adulthood is not merely a matter of age. A person of thirty may have a mental age of a child of ten. The mental age of one who may be an adult in years is partIy a matter of natural ability, partly of early environment, partly of experience, and partly of other factors.

For the purpose of definition we link the word "adult" with the word "education" -- adult, meaning a person who has passed beyond the age at which he would ordinarily have had education in school -- education, meaning anything wich can be taught to an individual to help him develop his various abilities to their fullest capacity.

Education should lead an adult to a more satisfying life, should assist the growth of his personality, prepare him for intelligent citizenship and make him feel that he is a person and not a slave, not a mere $\operatorname{cog}$ in the vast machine of modern life. 1

In America the plan for adult education dates from the early days of the Republic, and took the form of lyceums, mechanic institutes, and later chautauqua. College extension classes for adults began

1 Adams, James Truslow, Front lers of American culture, "A Study of Adult Education In A Democracy". Tharles Scribner's Sons, 1944) pp. 2, 7 . 
about 1891, the continuation school developed later, and in 1914 the Smith-Lever Act of Congress provided agriculture extension services to adults. 2 The American public school adult education movement began following the first world war. 3

The movement of adult education was greatly accelerated by the findings of an investigation made by Professor Edward L. Thorndike and his associates, with respect to the ability of adults to learn. In a chapter called Wew and Varlant Forms of Educational Service" from the book The American Education System, 1940, John Dale Russell, Professor of Education, and Charles H. Juad, Professor meritus of Education, both of the University of Chicago, make the following statements

It has long been mistakenly assumed by most people that the ability to learn diminishes rapidly after adolescence, and that the adult would always find great difficulty in undertaking a program of study. Thorndike and others have shown, quite contrary to the general assumption, that the ability to learn does not decrease with adulthood, that, so far as capacity is concerned, the average adult is probably more able to learn than the average child in the elementary school. Such findings have served to stimulate greatly the whole program of adult education and to encourage manj adults to undertake prozrams of study. 4

2 Cartwright, Morse Adams, Ten Years of Adult Pducation (The Kaomillan Company, 1935) p. 119

3 Bryson, Lyman, Adult Education, (American Book Company, 1936) Chapter x;. p. 130

4 Russell, John Dale, and Judd, Charles H., The American Educational System, (Houghton M(ifflin Company, 1940) p. 364 
In the Encyclopedia of Educational Research there is an article by Floyd L.Resoh on the scientific measurement of adult intelligence in which there is the followine information:

In revlewing researches in this area, intelligence is defined as "that which intelligence tests measure". Within the limits implied by this qualification, the research appears to justify the statement that measured intelligence declines slowly from about the age of 20 and more rapidly after 50 .

Conclusions:

Age beyond the twentieth year brings a decline in most functions called "intelligence". This decline is most evident in: the formation of new assoclations; speed as against power tests; dealing with spatial relations; and in auditory and visual memory. Decline with age is least evident in: vocabulary; information; and power as opposed to speed tests. 5

An important step in the development of the movement of adalt edacation is the founding of the American Association for Adult Education with offices at 1315 Cherry Street, Philadelphia, and 60 East Fortysecond Street, New York. It was formed March 26, 1926, with the ald of the Carnegie Corporation, for the purpose of study and promotion of adult education. It began puolishing quarterly the Journal of Adurt Education in 1929.6

The first president of the Association for Adult Education was Lean James E. Russell, Teachers College, Columbia University. He serred as president from 1926 to 1930. He was succeeded by Mr. Newton D. Baker, 1930-131, whose term expired when he was elected to member-

5 Hesch, Floyd I." $\frac{\text { Adult Intelligence, "Incyclopedia Educational Re- }}{\text { search", 1940, pp. 30-31. }}$ 6 Cartwright, Morse Adams, Ten Years of Adult Education, (The Macmilian Company, 1935) pp. 17, 18, 24. 
ship on the Board of Trustees of the Carnesie Corporation of New York. Mr. Felix M. Warburg was the next president. He wa followed by Mis. Dorothy Canfield Fisher, who held the office for two one-year terms. Her successor was Professor Edward I. Thorndike. Bverett D. Hartin became president in 1937; W1lliam A. Neilson in 1938; H. A. Overstreet, 1939; Alvin Johnson, 1940; Barry W. Chase, 1942; Alexander Meklejohn, 1943; and Austin E. HecCormick in 1944. The writer mentions these presidents because she expects to quote from their publications in later pages of this study.

Perhaps the most important single agency in the more recent development of the movement of adult education is the program conducted by the Federal Government during the years of the "economic depression", the 1930's. The establishment of facilities for adult education was considered a good method of furnishing work-relief for persons qualified to teach classes of adults who needed instruction along many lines. The magnitude of the emergency education program Is Indicated by data from the Advisory Committeo on Education; 44,000 unemployed teachers were put to work by June 1940, with classes in which $1,725,000$ persons were taught. 7

Adult education under the government included a wiae variety of instructional activities along vocational, cultural, citizenship, and $\overline{7 \text { Russell, J. D., and Judd, C. H., The }}$ "New and Variant Forms of Dducational Service". (Houghton Miffl in Company, 1940) p. 366. 
recreational lines. Programs were organized to apply to persons of all levels of educational attainment. One of the extensive projects dealt with the removal of 111 iteracy and much progress was made in teaching illiterates to read anc write. Americanization classes for the foreign-born were an important type of activity. Other programs were planned for those who had only a limited general education, and who wished to supplement it by further study. There was a widespread program of instruction in leisure-time activities and the parsuit of avocational and recreational interests. Upgradine vocational eaucation, where oy the worker is prepared for a position demanding increased technical knowledge or skill in the line in which he is employed, became a feature of many of the programs of adult education. Consiojerable interest was developed in programs designed to present information, and to develop wholesome attitudes on general problems of civic, social, and economic interests. Noteworthy in this connection was the series of community forums developed under the leadership of Commissioner John W. Studebaker, Commissioner of Education. More than 700 communities throughout the United States were aided through forums in 1939 alone. Four of these were in Kentucky, at Georgetown, Lexington, Paris, and Winchester. 8 Courses were added to the programs of graduate schools, for the preparation of those who were to engage in this type of educational service. The writer attended two such courses, one at the University of Chicago, 1934,

8 Studebaker, John T., Forum Planning Handbook, (The American Association for Adult Educetion, 1939/ p. 64 
and one at the University of Kentucky, 1938.

In discussing the purpose, emphasis, scope and limitations of acult education, the witer wishes to quote directly from statements made by persons of authority in this field. About the purpose of adult education, Mr. Newton D. Baker, in his address accepting the pres1dency of the American Association for Adult Education, in Hew York City, 1931, saids

The purpose of adult education should be expressed in terms not of desirability but of necessity. Our intellect is the only instrument that we possess whereby we may hope to direct our own lives or to meet intelligently the situations that daily confront us. It is therefore imperative for everyone of us to be unremittins in his efforts to train his judgment to aid his know ledge, and to increase his wisdom. 9

In his review of the social significance of adult education, Mr.

Worse Adams Cartwright saids

The doubters are right when they say that the adult eacation of fifty or a hundred years ago contained all the potentialities of the present movement. It did, but they were unrealized. Education was then under the dominance of ecclesiastical taboos.

The doubters are wrong in their belief that there is little new in the modern adult education. The emphosis is new, the belief that adult education will yield major satisfactions is new, the belief that adults really can learn is new, the conception of abundance of living as the undeniable educational heritage of every individual is new. The patterns as they strike the eye may seem the same, but fashions chanee. Those of tomorrow may be the same or they may be different. 10

9 Baker, Newton D., Address, Acceptance of Presidency of American Association for AduIt Education, New York City, 1931

10 Cartwright, Mrse Adarns, op.cit., p. 206 
In a builetin issuea by the Department of Public Instruction in Pennsylvania, the following statement is made ajout the scope of aajult education:

Adult Education in its accepted sense, is quite as broad and diversified as human learning. It mas be formal or informal, vocational or avocational. It embraces all levels of education and includes all departments. It consists of recreational as well as purely educational activities. Also, it should be understood that the term "adult" is intended to inclade all Individuals within the Commonweal th above compulsory school age. Il

Finglehardt and Englehardt have this to say regarding the limitations of adult educstions

Adult Education is limited only by the activities of people in all phases of living. It appears to fail when the program is artificial or superimposed. It is most successful when it deals with the realities of life or offers some stimulation after the routine of a workaday world. 12

One of the important considerations in adult education is the philosophy employed in its administration. The person in charge of an adult school must possess leadership; must develop a firm, friendiy, mutually helpful attitude among faculty and students; must prevent the occurrence of an atmosphere in which looseness of routine, of educational principles, or of ethical standards might arise. To do this one must have a comprehending training in education, in social and economic realities, and those finer sensibilities which may seem to be intuition but are in truth deductione

II Stodara, Alexander, The Public Evening Schools of Philadelphia, Bulletin, 1943-1944, p. 2

12 Englehardt and Finglehardt, Planning the Community School, p. 3 
based on experience, observation and a generous attitude. Pernaps greater than any other quality is a deep-seated love for people and a deep understanding of human nature. Such a leader will need some leisure time for professional reading and sensible mixing with community organizations in order to interpret the currenta that underlie community life. Thus the leader of an adult school can more convincingly direct the thought of various groups to better understanding and acceptance of the motives wich underlie his own professional philosophy and the philosophy of the school or system which he represents.

One of the first considerations in the orsanization of an adult education school is the philosophy of the teachers themselves. There are teachers who will not succeed in adult teaching; they ares those wose philosophy of education has not advanced beyond the "child centered class-room", or the "class-room controls needed for teaching adolescents."

Some difficulty has been encountered in maintaining programs of adult eaucation under auspices of the public-school system because of the tendency to use teachers of the regular day classes for the adalt classes. Particularly is this true when teachers of day classes are given extra pay to take on evening classes as an extra burden. There is a tendency to overload the capable teachers to the detriment of both the regular and the adult classes. Furthermore, many teachers who are successful with children and adolescents are unsuccessful with adult groups. I3

A better plan would be to make up the faculty of an adult school to a large extent of persons who are especially interested in this type

13 Engelhardt, Fred, $\frac{\text { Public }}{1931)} \frac{\text { School }}{531}$ Administration, (Ginn and Compan, 
of teaching; perhaps supplementing the regular faculty with an occasional person from the business or professional world, or with a teacher from the day schools who has a special slant on a subject or a special technique of presentation, or perhaps one who would enjoy the variety in type of teaching in order to stimulate and enlarge his understandings.

The recognition that the teaching of adults requires techniques which differ from those used in teaching children is very important. The child is learning for the first time, the adult is often relearning or breaking down preconceived ldeas; the child is sent, the adult comes of his own free will; the child must stay, the adult ill leave if he is not happy and learning what to him seems worthwhile; the child is forming a set of habits, the adult's habIts may have to be modified, but they are formed. In the case of the adolescent, there are a great many conflictine urges and drives which must be dealt with; while the adult is usually motivated with a desire to better himself. The adult is always very sensitive. The more he needs schooline, the more sensitive he is, and the teacher who accepts him as he $1 \mathrm{~s}$ and builds his self-respect can do him much zood, but one who tries to discipline him into conformine into patterns other than those he motivates for hinself will arouse his resentment.

With the above understanaings in view, these are the qualities which make good teachers for adults. First, he or she must really believe 
that the object of adult education is to aid men and women to desire to live with their fellow-men in love and understancine, and to share their concepts of a greater and fuller life. second, he or she hould be willine to accept the individual who attencis his classes as a valuable entity in God's worlà, and to devote his skills and learnings toward unfolding that personality.

If man is made in the likeness of God, mine is the privilege to help reveal his lod-like qualities. 14

The third quality of a teacher of adults is that he or she shall be a mature person, whose breaath of understanaing will invite the respect of his classes. Fourth, that his or her scholarship must be aynamic and progressive. However, his training and interests should not be so highly specializec as to remove him from sympathetic contact with the loarners. Lr. G. I. Haxwell said:
We have found that adults can be taught by people who are not far advancec beyond them in education, but who do possess understancings of the lives and problems of their students. In is means that the leadership for a great adult education movement is already among us -- we do not need to wait on the training of a large number of specialists. 15

The fifth quality of a good aulal teacher is that his personality should be inviting, with warmth and understanding devoid of sarcasm, irony, and coercion. Sixth, he must be willing to devote his time and interests for the csuse of adult education, because

14 From the poem Shall I Teach: Author unknown.

15 Maxwell, G. L., "The Educational Program of the vorks Prozress Administration", Lecture - (Midwest Conference, 1937) 
he considers it a great and purposeful life work. Seventh, that he or she will hare a wholesome outlook on all phases of life that oan inspire and influence bis students in working out their own problems. Eighth, that he has set for himself high goals of human understanding, but exemplifies the adage that, "Everyman knows something that I do not know, through that I learn from him." Above all, the philosophy of adult education teachers should be, "We have something which we think will make the lives of people richer and we wish to share it with others."

In closing this chapter, the writer will quote Dr. Philip I. Seman, General Director of the Jewish People's Institute of Chicago, who said:

Had our teachers, spiritual leaders, and institutions of learning at large fought for constructive ethical thinking, and had these institutions and leaders really taught us to live with our fellow-men in love and understanding, there never would have been the present need for anjone anywhere in the world to think in terms of world courts, leagues of nations, or activities orsanized to strengthen our international relations. Had these samo agencies in any way concerned themselves with some legitimate association of constructive ideas and ideals, there never would have been war, nor would we be facing the need to recapture from a torn and bleeding world those ideals of civilization which men die for, and to preserve them so that other men may have something to live for. 16

16 Seman, Dr. Philip I., Lecture, Mid-West Institute and Conference Adult Education, Gorge Williams College, Wisconsin. (Lecture Reporting Service, Chiceso, Illinois - 1937) 
DEVELOPMEAT OF

ELAMEATARY AND SECONDARY NIGHT SCHOOLS

FOR ADULTS IN LOUISVIHLE

In considering what has been done in adult education in Louisville,

it seems interesting to review briefly the early plan for this service.

First Night Schools in Louisville. As early as the year 1875-1876 there were three night schools in Louisville. They were for boys and young men only, and were financed by the Board of Trustees of the Public Schools of Louisville. The following table shows the enrollment, attendance, and cost of each. 1

TABIE I

Night Schools in Louisville, 1875-1876

\begin{tabular}{|c|c|c|c|c|c|c|}
\hline & $\begin{array}{l}\text { No. } \\
\text { En- } \\
\text { rol1 ed }\end{array}$ & $\begin{array}{l}\text { No. Re- } \\
\text { maining } \\
\text { Nintire Term }\end{array}$ & $\begin{array}{l}\text { Average } \\
\text { No. Be- } \\
\text { longing }\end{array}$ & $\begin{array}{l}\text { Average } \\
\text { No. } \\
\text { Teachers }\end{array}$ & Salary & $\begin{array}{l}\text { Cost } \\
\text { Per } \\
\text { Pap } 11\end{array}$ \\
\hline Eastern & 438 & 132 & 263 & 9 & $\$ 1,268$ & $\$ 4.82$ \\
\hline Western & 207 & 151 & 166 & 5.4 & 838.50 & 5.05 \\
\hline Central & 243 & 102 & 143 & 4.8 & 755.50 & $0 \quad 5.28$ \\
\hline Total & 886 & 384 & 572 & 19.2 & $2,862.00$ & 35.00 \\
\hline
\end{tabular}

1 Annual Report: Board of Trustees, The Public Schools of Louisville. (Year enaing June 1876) p. 31 
These schools were conducted from November through February each year. An interesting letter signed by F. C. Lober, President of the Board of Irustees and members of the Standing Committee on Night Schools, seems worth recording. It forecasts the probable fate of the school. By contrasting the schools it describes with the first night high school which will be described later we can see that interest in education for adults grew, that attitudes became very much better, and that the age of the persons attending was higher.

Night Schools For Boys and Young Men, 1875-1876

These schools were opened the third Monday in October and closed on the last Friday in February. They were designed to afford means of instruction to a class of boys and youns men that cannot attend the day schools, and they can accomplish much in the way of instructing some in the first rudiments of learning, helping others to a larger culture, and giving them power to help themselves. A large number availed themselves of the opportunities so generously provided by the Board of Trustees, attended regularly and made dil igent efforts to improve, while, I regret to state, a considerable number of evil-disposed boys entered only for the purpose of affording an excuse to their parents or guardians for being out at night, attended on an average one night each week, and resorted to every effort to annoy their teachers and to hinder those who really desired to learn. Unless the organization and discipline of these achools be brought to a high state of perfection, and none but well qualified and experienced teachers be employed, much of the expenditure for their support will literally be thrown away. It would be an excellent idea to expel, if possible, the disorderly element now in the schools and with the amount of money that could thereby be saved to establish one or more schools for the benefit of girls and young ladies who are compelled to labor during the day. Many would gratefully appreciate and glady accept the opportunity to make up for the neglect and deprivation of earlier years. 2

2 Annual Report: Louisville Board of Trustees (School year ending June, 1876 ) p. 78 
The members of the Board of Trustees composing the Standing Committee on Night Schools were Hessrs. John Drescher, J. B. Atkinson, Dr. H. K. Allen, John Hoertz, J. F. Canine, N. Finzer (honoraryl and F. C. Leber, President.

Early Hight Schools in Louisville. From 1876 until 1891 there were night schools conducted by the Louisville Board of Trustees. 3 They were located at the following places: (1) the Finzer School, on Broadway between Clay and Shelby, (2) the Main Street School, on ifain between Jackson and Hancock; (3) the Penth Ward School, at the corner of Green (now liberty) and Thirteenth, (4) the Madison Street School, corner Seventeenth and uuncan. The work was not offered at each place continuously curing the above ales. inementary school subjects were offered for persons unable to attend the day schools. The schools mentioned were for the white people only. There were two others, one in the eastern part of the city and one in the western part, for Negroes. The following table will show that each of the schools was well attended.

\section{TABLIS II}

Night Schools in Louisville, 1887

\begin{tabular}{llccc}
\hline $\begin{array}{l}\text { Name of } \\
\text { School }\end{array}$ & $\begin{array}{l}\text { No. } \\
\text { Enrolled }\end{array}$ & $\begin{array}{l}\text { No. at } \\
\text { Close of yr. }\end{array}$ & $\begin{array}{l}\text { Qeily At Grades 1-8 } \\
\text { Grance }\end{array}$ & $\begin{array}{c}\text { Averase } \\
\text { Enrollment }\end{array}$ \\
\hline Third Ward & 327 & 173 & 172 & 215 \\
\hline Ma in Street & 266 & 171 & 177 & 207 \\
\hline Madison Street & 420 & 269 & 292 & 338 \\
\hline Total & 1013 & 613 & 641 & 760 \\
\hline
\end{tabular}

$\overline{3}$ Report: Louigville School Board of Trustees. (Year ending June 1887) p. 7 
During the year 1886-1887 these three nifht schools were conducted for white people and two others for colored.

The following year, 1887-1888, the same three schools, Third Ward, Main Street, and iadison Street, conducted Night Schools, The total enrollment in the evenings the second year was 1030; number at the close of the term 681; daily attencance 687; average enrollment 814. This was an increase of 46 in daily attendance in grades 1 to 8. The next year 1888-1889, a night school was started at Seventeenth and Duncan, and although there were now four night schools the total enrollment was slightly less than in the three as they were conducted 1886-1888; however, the attencince was better. This is probably due to the fact that transportation in those days was difficult. The total enroliment was 1006; number of pupils at the close 679; average daily attenäance 666; aná average enrollment 794.

Teachers' Salaries. Teachers' salaries in the first night schools in Louisville averages $\$ 149.90$ each for four months, or $\$ 37.48$ per month. The average cost per pupil was $\$ 5.00$. In $1888-1889$ the average salary per teacher was $\$ 143.77$ for four months or $\$ 35.94$ per month; while the average cost per pupil was $44.78,4$

Newsboys Home Night School. While E. O. Holland was Superintendent of Louisville Public Schools, a night school was conducted at the

4 Report: $\frac{\text { louisville School }}{\text { pp. } 6-8}$ Boarà. (Years ending June 1888, 1889.) 
Newsboys Home at what is now the Neighborhood House, First and Walnut Streets, from September 1, 1895, antil July 1, 1913. The principal, Mrs. Wattie B. Tucker, was very interested in boys and her efforts to conduct a school in which the boys who worked could get an education were very commendable. The following copy of Hrs. Hattie Tucker's appeal for the school is found in the First Report of the Louisville Board of Education. 4

Superintendent E. O. Holland Louisville Public Schools

Dear Sir: The Newsboys Home School - or more correctly speaking, a night school conducted in a bullding known as the "Home for Newsboys and Waifs" - is unique in the fact that it bears the distinction of being the only one of its kind in existence. The building, light and heat are furnished by the Directors of the Home, while the equipment is supplied by the Board of Education, and is in every respect directly under its control. The session begins in the latter part of September and closes the following April.

Why have a night school here, instead of in a regular school building? When the Home was established there was a library well filled with books of every kind, but to the astonishment of the Directors they found thet many of the boys who frequented the Home were unable to read. Judge R. H. Thompson, founder of the Home, and other members of the directorate, set to work to meet the difficulty. Finally, an appeal was made to the school Bosrd to assist in establishing a night school in this building. No difficulty arose in explaining the need, and the result was, that the school was opened September 2, 1895, with a regularly appointed teacher, one who had had experience in teaching boys. Later girls were admitted.

The opening night found seven boys in the improvised school room. Ready for work? No: Simply determined to break up

4 First Report: Board of Education, Louisville, Kentucky. ( Year ending June 1911 and June 1912.) pp. 206, 207 
the school. When called to order one boy sald "How long"s this "ere school solng to keep?" Another said, "How much do you git for teaching as?" The teacher, realizing what was before her and feeling that she must be careful, asked, "What do you think I ought to get?" One boy said, "Eighteen dollars a month." The first boy responded, "What do you take her for, a scab?" The teacher was accustomed to boys and proved herself equal to the occasion, and about thirty boys enrolled ithin a few days.

The seven boys - charter members - proved valuable aides to the school, and developed into men that would be a credit to any community. One of them is an officer in the United States army and is stationed now in Alaska; one is a Heal th Officer in a Western City; one is a dentist in our own city; one is an electrician; one has a tailoring establishment; one is connected with a large ary-goods firm; one is dead.

The school continued to grow, and at the end of the third year the attendance demanded an additional teacher. After five years, bookkeeping was added to the curriculum. The faculty now numbers four teachers, with an annual enrollment of over one hundred and fifty. Since its opening about twenty-three hundrea boys and girls have received instruction in the school. During the past year sixty-two foreigners, representing eleven nationalities, were enrolled, raneing in ages from sixteen to sixty, not one of whom knew the use of an English sentence when he entered the school. Their progresa was satisfactory - in fact, surprising - ana many of them have returned tinis year, anxious to pursue their studies in higher grades. This is now the "Special School" for foreigners.

Hot a pupil has ever been sent out of the school for misconduct. A simple request from the teacher is always followed by instant obedience. Many of these boys and girls come directly from work and take up the evening task. Do they deserve our sympathy and help? The same teacher who took charge of the school on the opening night has been Principal during the seventeen years of its existence, and in adiition to this has the class of foreigners.

Respectfully submitted,

Mrs. Tuttie B. Tucker, Principal 
First Wight School for working Men. Through a conference with Hir. R. E. Dausherty, Assistant Superintendent, Louigville PubIic Schools, the writer found out some interesting things about the first night school offered in Louigville for working men only. It was conducted at the Manual Training High School, 1914-1915. Professor 0. I. Reid was Superintendent of Schools at the time, Mrr. R. P. Chapin was the principal, and Mr. R. E. Daugherty was the representative to the inoustries from the Board of Bducation. The school was advertised by meand of newgyaper notices and handbil1s, Hov. 16, 1914, and the large number of men who responded to the invitation far exceeded the expectation of the promoters. At first men came out of curiosity, but a large number remained and attended regularly for 20 weeks. Nearly every known occupation in Louisville was represented. There were helpers from the newspaper office; tobacco workers; wire-work mechanics; machinisto and machine apprentices; clerks; brewery hands; electrical apprentices; Mencel Box Company hands; Assistant Superintendent Mantel Company; Inspector, American Protection Company; lumber clerks; auto mechanics; drug clerks; iron-works hands; coffee roaster; organ builder; and helpers in lead and color work. The various classes and enrollment in each were: arithmetic 43 ; electricity 96 ; mechanical arawing 82; blacksmithing 58; wood-working 35; practical chemistry 19; machine shop 54. The average attendance was 390 and 443. The average ase of those attending was 24 years. The school was 
free to all under 20 years of age, and a fee of ten cents per week was charged those over twenty. Materials were furnished by the Board of Education. Teachers in night classes were recular day teachers, but in every shop class the teacher was a man who had practical experience in the industries. The following statement comes from the Fourth Report of the Louisville Board of Education: 5 From the interest taken, and the concensus of opinion of the men at the close of the session regaraing the value of the work to them, the night school was a success in every way.

The City Railway Company furnished patrons of the night school with school checks at half price, the same as for day pupils.

In a note from the principal, E. P. Chapin, to the Board of Education, we find the following statement:

The Board of Education and Superintendent of Schools have met a great need in a very wise and generous manner in establishing a trade night school, which, I believe, will become more and more valuable to working men in the city.

Ahrens Trade Night School. The next night school that this study will mention is the one at Ahrens Iracie school, 546 South first Street, which seems to have continued throughout the 1920 's until it closed in 1931. The Vocational Day School had been established. It attracted the attention of Mr. Theodore Ahrens, owner of the Ahrens Iron and Brass florks, who gave the money to establish the present school which bears his name, The Theodore Ahrens Trade High School, to provide instruction in a variety of trades for both

5 Fourth Report: $\frac{\text { Board }}{\text { ing June }} \frac{\text { Education, }}{30,1915 .)} \frac{\text { Louisville, }}{\text { p. } 241}$ Kentucky. (Year end̀- 
boys anc girls. Then grew the plan to extend its services to those who could not attend the day school. Miss Ethel Lovell, the princ1pal, reports that the night school was well attended; that, in fact, at times its attenaance was larëer than that of the day school.

The statistics for this school have been recorded with those of other night schools concucted at the same time, and the writer does not have the separate information. The average number attenaing, and the salaries paia for the last three years before the night schools closed is shown in the following table:

TABLE III

Night Schools in Louisville, 1928-1931

\begin{tabular}{ccc}
\hline Bate & $\begin{array}{c}\text { Áverage Number } \\
\text { Belonging }\end{array}$ & $\begin{array}{c}\text { Salaries } \\
\text { Teachers and Frincipals }\end{array}$ \\
\hline $1928-1929$ & 676 & $\$ 18,040.00$ \\
\hline $1929-1930$ & 967 & $20,359.77$ \\
\hline $1930-1931$ & 1,222 & $19,481.37$ \\
\hline
\end{tabular}

Ahrens Trade Nisht School served many people and its loss was keenly felt by those wo had not finished the courses they had started, after it closed in 1931.

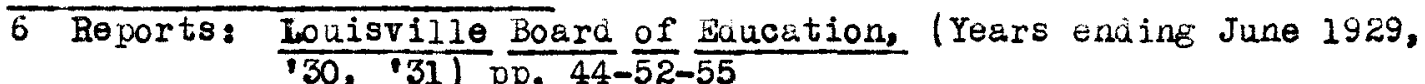


Elementary and Secondary Night Schools For Adults in Louisville.

The Federal Fmergency Relief Program of Adult Education. Free edacation for adulte in Louisville, Kentucky under the Federal Imergency Relief Administration began December, 1935, and was continued under the Works Progress Administration in April, 1935.

Its original parpose was to give employment to unemployed teachers. Statistics show that when the Federal Program started in 1933 there were reported 188,000 unemployed teachers in the United States. I Its major objective was to furnish constructive use of leisure time to the many unemployed persons. In other words, to help keop the mental balance of our citizens in time of stress; to direct thinking Into purposeful channels; and to enlarge abilities so that many could be prepared to enter new fields of endeavor when work again became avallable.

The funds with which to carry on this work in Louisville came from The Federal Emergency Relief Administration through the State Department of Education. In December, 1933, the Federal Fmergency Relief administered to the State of Kentucky the following sums of money, to be increased monthly as provision was made therefor, 2

1 Allen, IIndsey H., History of wPA Education in Kentucky, Thes is 2 Ibid.. p. 13 University of Kentucky, $1 \overline{94} 1$, p. 8 


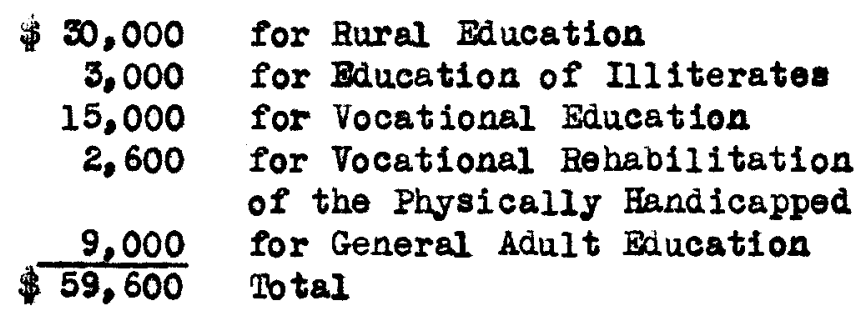

Loulsville shared in this grant, although the specific amounts for Louisville are not available, since the program was administered on a state-wide basis.

The State program was under the direction of ir. James H. Richmond, Superintendent of Public Instruction for the State of Kentucky. The supervision was rested in Homer. Hichols, Director, Division of Special Eucation. In Louisville, the Board of Education through 14. Frederick Archer, Superintendent of Pablic Schools, sponsored the Louisville Adult Education Program. Mr. R. E. Daugherty, Assistant Superintendent, who had been interested in earlier night schools in Louiaville, was appointed co-ordinator for the program and the office of the Iocal Supervisor of the FRRA Program was located next to his office. 3 The first local supervisor was $\mathrm{Mr}$. Fred Conn, who was followed in six monthe by He. 0. A. Harris, who in turn was followed by Mr. L. L. Hadson, June 1941. Mr. Hudson served one jear. After Mr. Hudson left the program, the writer supervised the work at Monsarrat School, and all reports were made directly to Mr. Lindsey E.

3 Daugherty, R. B., Information through personal interview. 
Allen, State Supervisor of the program.

The program was promoted through the louisville newspapers, churches, clubs, industries, and public libraries. Miss Sara Landau was appointed organizer of classes.

At first the work was variec and somewhat unrelated. Any group of twenty or more persons could request a teacher for any subject. Inglish was stressed. If an unemployed teacher who needed work was available a class was started. By the end of the third year a total of nearly 100 teachers had engaged in the work. The average number per year was thirty-seven. There were established classes in literacy and Elementary Education for very underprivileged persons in the County Jail and The City Work-House; there were teachers who worked with the partly disabled persons in the convalescent wards of the Louisville City Hospital (now the General Hospital); with convalescent persons in Waverly Hills Sanitorium; with persons who needed mental interests in the Cook Benevolent Home; and with persons who ware able to learn handicrafts in the Kings vaughters Home. There were two teachers at the Children's sree Hospital in occupational handicrafte; there were classes in parent education and paychology at the librarles; and for Parent-Teacher Association groups at their respective schools. There were classes in English and elementary school subjects including physical and mental hysieno at varlous community centers. Many illiterates were reached by house to house 
calls. Some of the centers which cooperated in the elementary and perent education phases of the WPA Adult Education Program were: 4

The Wesley House - Shelby and Washington Streets The Rose Hudson Community Center - 2509 Portland Avenue The Baptist Mission - Brook and Jefferson Streets The Volunteers of America - 401 Fehr Avenue The Cabbage Patch Settlement House - 1413 South Sixth Street The Neighborhood House - 428 South First Street

There were classes in Workers Education in some of the industries. Other classes were established in the Y.M.C.A.; the Y.W.C.A.; and the Y.M.H.A. English and Horeign Languages were taught; also, there were classes in Americanization for the foreign-born who desired to learn to read and write Fngilish and to understand something of the customs of the United States and the form of government.

Peachers were placed where there seemed to be the greatest need for them. Although any center, which had as many as twenty persons who wished to be taught could request the services of a teacher, not all of them could be supplied because the FERA restrictions to persons in need limited the number of competent teachers arailable. Then too, some of the experienced teachers who were available were not able to hold the interest of adults.

The more academic branches of the Adult Education Program were offered in the public libraries. Mr. Harold Brigham, Louisv1lle L1-

4 Harris, 0. A., Bulletin, WPA Classes In Iouisville, 1936 
brarlan, and Miss Bernice Bell, Children's Librarian, were especial1y interested in the adult program. Also, close understanding existod between the teachers and the librarians in charge of all departments of the main library and all its branches. This was partly due to the fact that Mr. 0. A. Harris, Local Supervisor, held the teacher'g moetings in the library auditorium every Saturday morning, and various members of the library staff met with the group.

Perhaps a very brief picture of the work done at some of these places is appropriate here.

The Rose Hudson Community Center. In Portland, the oldest section of Louirville, Mrs. Katherine Le Gros conducted literacy classes and taught groups in elementary subjects and homemaking. The men and women who attended came from the homes in the community. Some had little or no schooling, while others had not had an opportunity for years to get instruction. They responded to Mrs. Io Gros, who was kind and capablo. An interesting project continued there for five years. Hirs. Le Gros, with an occasional assistant, brought interest and color to lives that might otherwise have been exceedingly drab.

The City Hospitel. At the City Hospital, Mrs. Anna Mo Carrico built a very interesting project in the literacy and elementary field. She not only taught many convalescent patients to read and write, but she also provided others with reading materials and handicraft. 
Mrs. Carrico followed up some of the cases when they left the hospital, and was the means of directing many of them to new interests, new Iife, and new hope. She was especially interested in the "pol10" cases, and visited them in their homes after they left the hospital.

Americanization Classes. Classes for foreign-born persons who were preparing for citizenship were taught at the Y.M.H.A. by Hiro. Bva Snyder, and at the Neighborhood House by Miss Monta Rae Tunstall. 19rs. Snyder was herself a naturalized smertcan citizen, born in Russia. She is an enthusiastic person who speaks five languages. She served during World War I as a Red Cross Nurse. Mrs. Snyder worked with the adult program for a year or two, but hiss Tunstall continued until the close of the work in 1943. Several organizations became interested and there were capable sponsors the Refugee Relief Association, The Council of Jewish Women, The Colonial Demes, The Daughters of The American Revolution, and The Women's Aurillary of the American Legion.

The Transient Bureau School. One of the very interesting projects was conducted at the Louisville Transient Bureau, 307 South Fifth Street. Here, for three years, Miss Elizabeth Green aided in the rehabilitation of unemplojed men by means of the one-room countyschool technique. She gathered about her books, charts, writing materials, etc., and with a branch reading library furnished by the Louisville Public Library, she tausht men of varying abilities, from 
total illiterates to college graduates. These were men who, while wandering from place to place throughout the nation, in search for work, were housed for a time at the iransient Hotel at the old Labor Temple. Some of them dropped into school for just a few lessons in letter writing, arithmetic, or spelling, while others came constantly for several months. This was one of the very first projects under the FERA, started December, 1933, while Hr. Fred Conn was supervisor, and it continued after Hay, 1935, under the WPA, until the Transient Bureau closed in the fall of 1937. Miss Green has followeo up her acquaintance with some of these men and is gratified to learn that many have responsible jobs and are worthy citizens. She says, "Unemployment during those years was more of a disgrace to the nation than to the individuals who were its victims."

Waverly Hills Sanitorium, At the Waverly Hills Sanitorium, persons suffering from tuberculosis were given active participation in the Adult Education Program. Many dreary hours were brightened by Mrs. Ester Haskill, who used a system of teaching by radio. Each pupil used an ear-phone attached to his bed. Mrs. Haskill sat on the porches with the patients who were able to be up, and her lessons and lectures were broadcast throughout the building. She brought so much good-fellowship and cheer that the patients looked forward to her classes twice weekly. Throush these lessons some of the patients were prepared to enter regular high school or college after they were discharged from the hospital, while others were enabled to take 
positions through which they could be self-supporting.

These are just a few of the projects that might be termed "humanitarian". There were others, but the writer mentions these because she $v$ isited each of them and is reporting first hand information.

Vocational Classes. Classes in business education were conducted 1935-38 in the National Theater Building. Here Miss Vera Herrell, assisted by Mrs. Madge Stoner, and Mro. Henrietta Roach taught typewriting, shorthand, business spelling, English, filing and bookkeeping.

The Parkland Library Business Education Classes were successfully active for several years. Here Miss Delazine Hardin, assisted by Mrs. Julia Hamilton, and Has Florence O'Bryan, taught classes in shorthand, typewriting, and business practice. This service was very valuable. In both the centraliy located center and the Parkland Center which is in the southwest section of thecity, many persons were trained in skills which helped them gain livel thood.

Branch Llbrary Classes. Other classes were held at Shawnee Branch where 1r. 0. A. Harris, supervisor, conducted a current events class, and Miss Rose M. Reilly taught classes in English diction and the review of current literature. At the Highland Branch, Miss Reilly taught classes in Finglish; Nors. Winnefred Strode taught French; and the writer trained groups in parliamentary procedure and public 
speaking. At the Crescent Hill Branch, the socially-minded Ifiss Sallie Berryman sponsored an active Adult Fducation Program from 1934-1938. Here Mr. Harris conducted a current events discussion group, Mr. J. C. Heckel taught German, and the writer conducted classes in English, parliamentary procedure, and interior decorating.

Main Library Classes. The small auditorium in the basement of the Main Library, at Fourth and York Streets, was the center for several active and interested sroups. The first classes organized to meet here were conducted by Miss Sara Landau in economics and English. When Miss Landau left the program, February, 1935, these classes were continued by the writer, who also organized a public speaking class and conducted an open forum for the discussion of problems of puolic interest. Languages, French, German, Spanish, and Italian, were taught by Mr. Jules Moran, and Mr. J. C. Heckel, while Mtss Mabel Nichols directed a parent education group in psycholozy and children's problems.

The classes at the libraries were very active for three years, 1934 through 1937. They were interrupted by the flood, 1937, but some of them resumed meetings after the libraries were reconditioned. A fow groups continued meeting in libraries until 1941.

These informal classes enrolled numerous persons. The exact enrollment in each is hardly available now because teacher's reports were 
not complled into one report from the city of Louisville to the State Office. Howerer, the writer helped Mr. Harris compile data from time to time and she has in her files a record of the totals. By comparing these with the record given by the State office for 1934 to 1937, she considers these figures accurates

$$
\begin{gathered}
4,525 \text { enrolled in General Education Classes } \\
1,478 \text { enrolled in literacy Groups } \\
1,007 \text { enrolled in Parent Education and Current Brents } \\
\text { Classes } \\
\overline{7,000} \text { Total from } 1934 \text { to } 1937
\end{gathered}
$$

During the summer of 1937 a survey was made by WA teachers which revealed 5,880 total illiterates who wore visited and invited to take advantage of the opportunity to learn to read and write.

Hot all the 7,000 persons who enrolled in the general education classes were seeking "education" in the sense that we usually understand the term. They were seeking something to satisfy their needs or interests. The significant fact is that they sought the satisfactions by attending classes. The reacer will remember that many of these persons were victims of enforced idleness which might have led into various unworthy channels. Some attended classes out of curiosity or merely to pass the time; became interested; and started programs of study which opened new fields of interest and developed their abilities.

Or is in and Development of The Adult Bducation High School. The first three years, 1934-1937, brought to 1ight the great need for an organ- 
1zed secondary school for adults. The classes under the FERA and PA had been informal, somewhat unrelated, and chiefly concerned with morale bullding.

It happened that in Loulsville several very capable teachers were available. Some of these were women teachers who had left the profession because they preferred marriage and home-making, or because they were forced out, by the ruling of the louiaville Board of Education, which did not permit married women to teach. When the economic depression came, they found it necessary to use their earning capacity, and since they were trained teachers they were glad to get the work. Others had retired from the classroom because they had sufficient funds to enjoy living wthout earning. They lost their savings, through bank failures, and they too had to return to work. Then too, the teaching fleld was somewhat overcrowded. Many persons who had been emplojed in industry during the previous years were thrown out of work wen the induetries closed. Some of these were college graduates, who could qualify for teaching jobs by taking a few courses in education.

During the first years of the adult program, the organization of classes and the gaining and holding of interest were entirely the responsibility of the teacher. Some failed, others were quite successful in holding the interest of large classes, and, though knowing well the temporary nature of the program, they planned their 
work, with the view that all education is worth-wh1le, so that when one of their number was cut off the program by WPA rulings, another could take the place and work toward a permanent program.

The writer of this thesia observed much of the work of various teachers. She became interested in the belief that there should be an organized secondary school, so that persons who were eager and willing to attend regularly might pursue a planned course of study. She set about trying to show the WPA Supervisor that such a school was feasible. She began a closer study of the persons who came to her classes at The kain Library. Many, having been cut off from former pursuits, were seeking mental interests. Some were unemployed and spent their days in endlessig searching for work. often they dropped into the library to rest or read. In that way they saw the bulletin-board which announced the WPA classes. Others were employed at any kind of job that was available; while still others held sood jobs but were in need of stimulatiog interests. One thing was ovidents they were all seeking to adjust to the emergencies which confronted them in an economic depression. They needed encouragement; they needed guidance; they needed more training. Some bad started to work too young; others had held blind-alley jobs; others had job training for wich there was no demand; then, too, there were few available kinds of work. There were in each class bright, ambitious persons who were wlling to study and to help others. Some of these clasa-members were selected for class-secretaries and group leaders. 
Right attitudes of mutuel helpfulness quickly developed.

By using questionnaires, personality sheets, and finally standardized achievement tests, the witer sought to determine the placement needs of such a group of persons. 6 The first groups to be teated were meeting at the Main Irbrary. Of 150 class members, 109 took the tests. The following results were obtained,

10 persons had reached a grade level of 6 or below

18 persons had reached a grade level of 7 or 8

47 persons had reached a grade level of 8 to 10

20 persons had reached a grade level of 10 to 12

10 persons had reached a grade level of 12 to 14

4 were college graduates

Twenty-six of the 109 had attended the Y.M.C.A. Night School or one of the business colleges; but few could, at that time, afford to pay tuition.

These findings served to strengthen the belief that IIPA Education could best serve Louigville by establishing a free school of secondary level where adults could get standard work. Then with the help of Miss Rose M. Reilly, the writer made observations of the classes which met at the branch libraries. The results were simflar. The writer then studied qualification of the teachers. She found that there were several teacherg in the program with high school experience and thus she reasoned, "Here are people who need to be taught high school branches of study, and here are teachers who can do the

6 Cooperetive Achievement Tests, (Amerioan Council on Education, New York, 1935) 
work. Why not bring them together?"

The FERA was transferred to the Works Progress Administration in May 1935, and Mr. O. A. Harris continued to serve as Supervisor of the work. Therefore, as soon as she completed the above mentioned observations, the writer begen to persuade Mr. Harris to bring the qualified teachers together in one centrally located place, and to schedule classes in all four fields of the secondary school, Inglish, mathematico, social stuáles, and natural sciences.

Mr. Harold Brigham, Librarian of the Louisville Public Llbraries, al 80 became interested in the idea, and considered the organization of such a school at the Library at Fourth and York Streots, since there were three rooms and the auditorium at the library already in use by UPA classes. However, Mr. Brighem felt that an organized school would soon outgrow the library capacity; also, that it was the function of the Board of Education to furnish a school building for educational purposes.

During the months of March through June, 1936, Mr. O. A. Harris, through his current events classes, and the witer, through her Inglish and public speaking classes, tried to find out the concensus of opinion or desire for an organized school for adults. Much enthusiasm was expressed and reported.

On the evening of July 16, 1936, a mass meeting was held at the bandstand in Shawnee Park. Several entiusiastic women volunteered to 
work for a high school and requested that it be held in the west end of the city. Mr. Harris agreed to make inquiries about possible meeting places. He consulted Dr. Zenos Scott, Superintendent of Louisville Schools, and it was agreed that the portable buildings at Shownee High School might be used, provided that the cost of utilities and janitorial services were paid by the users.

On September 7th at 7:00 P.M. registration began for the first term of the Adult Night High School under the WPA Educational Program. It was soon seen that the number who registered would not be sufficient to meet the $\$ 57$ per month necessary for the use of two portable buildings. The enrollment fell below the expected number because the nucleus of the movement was in the central part of town and attendance at Shawnee was prohibitive because the distance required carfare.

The next step was to find a cheaper place to meet. 7 This was accomplished by Miss Asanath Brewster, one of the members of the faculty of the new school, who, through the pastor of the Baptist Church at Forty-fourth and Kain Streets, secured the use of three Sunday School rooms for $\$ 25$ per month. This amount was paid by the teachers and pupils.

7 Under the WRA Iuling, Operating Procedure, G-I, (Funds For Salaries, Sponsor's Contributions - Housingl 
Classes were begun in mathematics, social studies, general science, and English. The first teachers were Miss Elenora Smith, graduate of Nazareth College, mathematics and science; Miss Asanath Brewster, graduate of Indiana State Normal, history and social studies; the writer, graduate of Bastern Kentucky State Teachers College, English.

For Six weeks, the Adult Night High School in the Sunday School rooms worked very well, but when the weather became cold the only method of heating was by gas stoves. Then too, the church decided to use the rent money to paint the inside of the building. The combination of bitter cold weather, gas fumes and turpentine odor forced the decision to move.

One of the class members then offered the use of her home which was furnace heated. Since there were seldom more than twenty-five persons present at a time, the offer was accepted and the school moved to the home of Mrs. Nina Burkhead, Thirty-ninth and Harket Streets. Here the work continued until the end of the semester. The last meeting was that memorable irlday in January when flood waters began to rise in the west end of Louisville. Some of the streets were covered with water when teachers and pupils started for home.

After flood destruction was cleared away, the school began a second semester. This tine the use of the Lutheran Church School at Thirtyseventh and Del Park was obtained. Miss Rose M. Reilly was added to the faculty. Miss Rellly brought eight pupils from the Jefferson 
Street Branch Library English Class, and four from the English Class at the Southern Bell Telephone Company. Also, since flood waters had caused the Maln Ilbrary Finglish Class to close, some of the members of that group came to the Aduit High School. Perhaps it should be noted here that the various projects in other places had continued; that only the teachers who were needed for the high 8chool work were permitted to leave their original classes. Both Mas Rellly and the writer continued to teach day classes, as well as the night classes. This seemed expedient since the success of the High School Project seemed far from certain.

The second semester ran more smoothly, attendance was good; the teachers succeeded in holding and increasing interest; and by June 20, 1937, fifty-four persons had completed ono semester of high school work, twenty-five of them one year.

During the entire first year there had been many requests for the Adult High School to be centrally located. Some of the library classes, which had been disturbed by the flood, wot during the spring and summer months of 1937 at the thodist Temple at Sixth and Broadway. In Alugust a mass meoting was held at the Temple to consider the continustion of the Adult High School. Mr. Harris was asked to confer with Dr. Zenos Scott and request the use of a school building. 
While the group waited for lir. Harris' report, they proceeded to work-out class schedules and to formulate classes. By September 7. 1937, 99 persons had registered for high school work. The groups met at the Methodist Temple for two weeks; the class organizations were completed and everything was ready but the housing. ir. Harris had not sacceeded in getting the use of a school building. Finally, through the efforts of Miss Mary Sue Bush and Miss Caroljn Graft, young women wo wished to attend the school, the offer of the use of a school bullding came. They had called on Reverend Francis J. Timony, pastor of the Holy Hame Catholic Church, at Third and Heywood. Father Timony, who had the economic and social welfare of his parish very much at heart, said:

We have a school building which we use during the day, but you are welcome to use it in the evenings. It is paid for and we'd like it to serve as broadiy as posalble."

This graclous offer was gladly accepted and the Adult High School moved to the southern part of the city, September 15, 1937. A few of those who had registered could not follow, but gince janitorial service and utilities were includec with the use of the school, the expenses were very light, being confined to carfare and books.

The attendance increased, and by the end of the first semester 110 persons were eligible for credit. There were 190 enrolled during the second term. Miss Elizabeth Green, graduate of Transylvania College; Mrs, Winnefred Strode, Mo., Columbia University; and Mrs. 
Mrs. Fiter Hasicell, graduate of Hazareth College; were added to the faculty, which now consiated of Miss Asanath Brewster, Hisa Rose Reilly, Mss Elizabeth Green, Mrs. Minnefred Strode, and Mrs, Ester Haskell. The writer was made principal.

The curriculum was planned on a credit basis, sixty clock hours were allotted to each subject. In addition to the four major fielda, Fnglish, mathematics, science and social sciences, four electives were offered, shorthand, typing, current events, public speaking, and Latin. The class in latin was in reply to a special request by a number of persons who desired to become trained nurses. The writer is glad to report that 85 per cent of the original enrollment had followed through the seeming labyrinth, and that by the end of the second year some of them, who had done previous high school work, were ready to graduate. Also, 80 per cent of the first enrollment continued until they completed four years of high school work. The following table was taken from material contained in a report made to $\mathrm{Mr}$. O. A. Harr1s, WPA Supervisor, June 1, 1938, by the writer. It contains the type of information which was characteristic of HPA requests.

\section{TABLE IV \\ Characteristics of Student Body Adult Education High School 1937-1938}

Number enrolled first semester: Wen 50, Women 60, Total 110 Number enrolled second semester: Men 91, Women 99, Total 190 


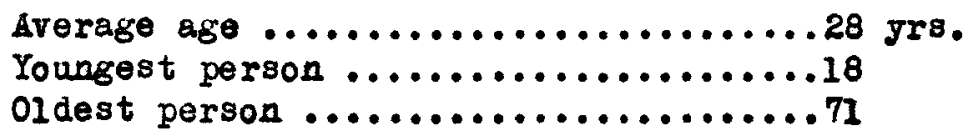

Number unemployed .................30

Number who earn less than $\$ 15$ weekly...52

Number who earn more than 15 veekly...62

Number who contrioute to family bdgt...28

Number of heads of families .........45

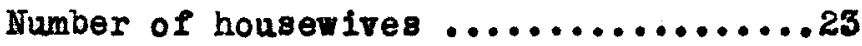

The classes were held from six to ten o'clock each erening, Monday through Friday. Each class met twice weekly, and the periods ran one and three-quarters hour. A fow classes were offered once per week for public discussion, current erents and public speaking. A student could attend two, four, or five evenings per week and earn one to five credits. Sixty clock-hours in attendance were required for each credit. 8

The First Graduating Class. The first persons to complete the high school course under the Adult High School were Mrs. Mae S. Beams, Miss Florence Stith, Miss Bertille Kollros, Miss Ruth Gamble, Hir. Willard Lambertus, and Mr. D. N. Slaughter. They were awarded diplomas at the First Christian Church, by Mr. R. B. Laugherty, Assistant Superintendent of the Louigville Public Schools, on the evening of June 9, 1938.

The honor graduate was Miss Bertille Kollros, 211 South Thirtyeighth Street, a bookkeeper, who was not too tired at the end of a day filled with figures to spend three and one-half hours at the

8 Report: To WPA State Office, By the Principal, June 1, 1938 
night school. In the audience were the two children of Mrs. Mae S. Beams, who smiled proudly at their mother - a stenographer in the day time, a high school student at night, and at all times a cheerful, helpful parent. MAss Ruth Gamble, 242 South Thirty-ninth Street, was a member of the Public Health Nursing Service. She had earned her nurse's diploma before a high school education was a requirement. Her diploma helped her to meet the new standards.

One of the graduates who "quit school" just because he wanted to was Willard Lambertus, 4124 River Park, who aropped out of hale High School in 1934 in order to help his father in his shoe repair shop. It is an interesting sidelight that willard is today, summer, 1944, Captein Willard Lambertus in the United States Air Force. Also, at this writing, Florence Stith, who dropped out of the Iouisville Girl's High School in order to help her widowed mother, has since graduated from the Louigville Baptist Hospital School of Nursing. She is a Reà Cross Nurse now. Mr. D. N. Slaughter is an optician and is connected with a Louisville optical company.

One point of interest at this first commencement was the good fellowship expressed by the ministers who represented different reIlgloug faiths, in their cooperation with the program of adult education. Dr. Homer Carpenter, pastor of the First Christian Church, arranged to have the commencement held in the smaller auditorium of his church; Father Paul Durban, director of education at the Holy 
Name School, which had housed the adult school, gave the invocation; the Reverend Hansford D. Johnson, pastor of the Broadway Baptist Church, pronounced the benediction.

The address of the evening was made by Mr. O. A. Harris, who was introduced by Willard Lambertus, President of the class. Music was furnished by members of the student body. The first graduates have set a standerd which all other classes have had as a challenge.

Adult High School Hoved to Honsarrat School Bullding. The program and progress of the high school project were carefully observed by 2. large number of puolic minded individuals and groups. Among them were several groups of Louisville club women. The results of the first two years pleased them. Then one of the clubs decided to come to the aid of the school. A committee from the League of Women Voters calleci upon Dr. Zenos Scott, Iouisville Public Schools Superintendent. They requestec the use of a centrally located school building. Nonsarrat School was chosen because it was near the public library wich the students could use for reading and reference work. The request of the committee was granted and the school moved to Nonsarrat in June 1938.9

The student body was very happy about the change. They were saved hours of time which could be used in study. Many of them came from

9 Record, Works Prosress däministration, State office, June 1938 
jobs in stores in the central part of town and could go the library after work or com directly to the school. Although the building was an old one, it was equipped with large desks, blackboards and some maps. It was quite satisfactory, and the classes enjoyed having a place centrally located. Those who had previously attended classes in the library showec other students how to use its reference rooms and open stacks, and from the very first day at Monsarrat the library became an integral part of the school.

The First Summer School at Monsarrat. The Adult Education High School moved to Honsarrat School June 15, 1938. The first summer school began at once. In order to conform to the sixty hour per credit regulation, it was found that students would have to attend five evenings per week, two hours per class. Therefore, the summer school was planned for six weeks, and offered two classes per evening, five evening's per week. A student could attend two hours per evening and earn one credit, or four hours and earn two credits. The classes were from $6: 00$ to $8: 00$ and from 8:00 to 10,00 P. If. The work offered during the summer was planned to help citizens know more about Kentucky. The English class studied Kentucky authors; the history class studied the history and geography of Kentucky; the science class worked on public health problems of Louisville and Kentucky; and the general thematics class worked on local business problems.

There were 100 enrolled, and 76 of the number attended the entire time, five evenings per week for six weeks. 
Progress in the Central location. After the Adult Education High School moved to Monsarrat Junior High School Building at Fifth and York Streets, the enrollment increased rapidly. The close proximity to the public library was a great advantage. The coordination of facilities, the use of books and other materials, the reading rooms, which the adult students used for study, all helped to increase interest. The careful plannins of the curriculum, and the agsressive atmosphere of the school contriouted toward its accrediting. Mr. Mark Godman, State Supervisor from Frankfort, visited the school in June, 1938, checked its procedures carefully, and agreed to approve its credits for college entrance. 10

The following is an excerpt from a letter to principals of louisville High Schools, by Charge of Seconàary Education:

Relative to accrediting work done by the WPA Night High School, I am informed by Mr. Hark Godman, Director of Supervision, State Department of Education, that "At the meeting of the accrediting Committee on January 28, 1939, the following notion was passed: 'It was moved by $\mathrm{Mr}$. ligon that pupils in the adult education schools should get credit for work completec. Seconded by Mir. Deacon. Motion carried"." In accordance with the foregoing, you are authorized to accept credits from the local IPA Aault Education High School, when properly certified by the principal of that school.

10 letter of Approval Recorded in WPA Records, State Office, January, 1939 
It was distinctly an adult school, planned around adult interest; totally voluntary and, as far as possible, informal. The enrollment increased rapialy, practically doubled each year until it reached the peak of 1251 persons enrolled in 1940-1941.

Commercial Classes Moved to Monsarrat, The first year in the central location, 1938-1939, marked another change in the prosram of adult education. The commercial classes, which had been meetIng in the National Theater Building at Fifth and Walnut, were transferred to the Monsarrat School. Inis was done to help unify the program offerings. The classes were not, at that time, accredited as part of the high school curriculum; however, judging by the number of students who prepared themselves for employment, passed civil service examinations, and reported up-grading in the jobs which they held, it can be said that the classes did creditable work.

Miss Vera Herrel was in charge of this work, assisted by Miss Florence O'Brian and Miss Delazine Hardin. They served about 150 students per year for three years. In 1941 Miss Herrel was transferred to the Bowman Field School which prepared soläiers for clerical jobs, and hiss Hardin took charge of the classes at llonsarrat. The number of teachers and the number of pupils served were thus curtailed.

Elementary Classes at Honsarrat School. The elementary school, known as the preparatory department, was started at Monsarrat in 1939. Here 75 persong were given training the first year in grade school sub- 
jects. The work covered grades one to eight. Miss Mary flice Thompson, Mrs. Claude Waggoner, and Mlss Elsie Boles taught the elementary classes 1939-1941. In 1941, M1ss Thompson and Mrs. Wagsoner left the program and Miss Boles was transferred to the high school department. From 1941 until the school closed in 1943, Mrs. Sallie Clark and Hrs. Lelia White taught the elementary classes at Monsarrat.

A number of interesting stories could be told about the benefits received by persons who attended these elementary classes. One is the progress made by Mr. Charles Blank. Mr. Blank entered the sixth grade in 1939. He attended every term including the summer schools; completed the elementary school and three jears of high school by June 1943; followed the adult school to Ahrens Night High School 1943-1944; anà graduated with the first class from that school June, 1944. Mr. Blank now is in the Speed seientific School at the University of Louisville. Il

The Assembly Pragrams of the Adult High School. The assembly programs were planned to give unity to the school. They were instructive as well as pleasant. They tried to bring larger understanding of social, civic, and economic problems. There were current events discussions, lead by Mr. O. A. Harris, Local Supervisor;

II Permanent Records of Ahrens Night High School, 1943-1944 
sometimes special music and always group singing. From time to

time, there were visiting speakers. Some of the visitors were: 12

Dr. I. R. Alderman, Director H.P.A. Education, Washington, D.C. Miss Ruth Kotinsky, Editor "Community Councils", Washington, D.C. irr. Harold Brigham, Louisville Librarian

Nayor Joseph D. Scholtz, Hayor of Louisville

Mir. P. Kins, Editor Kentucky School Journal

Mr. Frederick Stamm, Director Adult Rucetion, University of

in. Grady Rowntree, Louisville Public Health Officer Louisville

Mr. Lindsey E. Allen, State Director of WPA Bducation

Captain Lee Cary, First Aid Demonstrator, louisville Police Department

Mr. Orville Stivers, Superintendent Jefferson County Public Schools

Miss Florence Housewald, Supt. Louisville Public Health Nurses Dr. J. K. Long, Supervisor Secondary Education, Louisville PubIic Schools

Rev. Felix Pitt, Superintendent Louisville Parochial Schoolo Miss Anna J. Haynes, Director Heal th Education Research

Mrs. Lillian Jones, Former Supervisor Heal th Education, Jeffer-

Mr. Hugh Hughes, Government So il Conservationist son County

Mr. R. E. Daugherty, Assistant Superintendent Louisville Public Schoole

Dr. Maurice Seay, Bureau of School Service, University of Kentucky

Lieutenant B. E. King, Education Director at Bowman Field Milss Lene Hilirich, Louisville Art Supervisor

Mr. L. L. Hudson, District Supervisor WPA Education Projects

Mr. Roy Chumbler, Supervisor viorkers Education

Rev. Homer Carpenter, Pastor First Christian Church

The assemblies were well attended by both regular students and

visitors. Whey were definite examples of democratic practice in

education. All were invited, none had to attend. They furnished

opportunity for timid or sensitive adults to share in the school

eervice without being regularly enrolled. An adult was an invited

guest until such time as he had the courage to come and say, "I need

more schooling." Many came with their friends to the assemblies, or

as visitors to classes. When they saw that others, as old as they,

$\overline{12}$ Records and Reports of the Principal, Adult Education High School 
were going to school and enjoying it, they too came. The growth of the high school, from 81 the first year to 1251 the fifth year, is partly explained by the informal and democratic practice of the entire school. The writer feels that it was through the assemblies that the real philosophy of the school reached the people.

The Defense Training Program. During the early part of 1941, preparatory classes were organized for men who desired to take examinations for service in the Air Corps or Mechanical Forces. The Officer in Command of Education at Bowman Field visited the Adult High School and arranged to send groups of 10 to 20 young men each six weeks, one third of a semester, to work in the classes in mathematics and English vocabulary. Miss Thelma linncy was in charge of this specific part of the program. the classes served 150 men the first semester, and continued to serve on a smaller scale until the close of the school June 1943. 13

The Alumni Association. When the second class was ready to graduate from the Adult Ecucation High School 1939, the first class of $81 x$ organized themselves into an Alumni $\mathrm{Club}$ and plannea to honor the new graduating class. They planned a dinner and social function at which time they received the new graduates as members of the club. They became known as The Alumni Association of The Adult School. From year to year they gained interest and added members. When the 
school closed there were 176 members. They formed a strong and progressive organization which loyally backed the school in appreciation of the opportunity which it had given them. They assisted one another; planned social and recreational programs for their own group and for the school; attended assemblies; brought in new students; and from time to time helped with the clerical work, and exchange book sales for the school. Then the school closed, they appealed to the mayor and other public minded persons for the continuation of adult education opportunities in louisvilie. Hrom this group of 176 grauluates there are today:

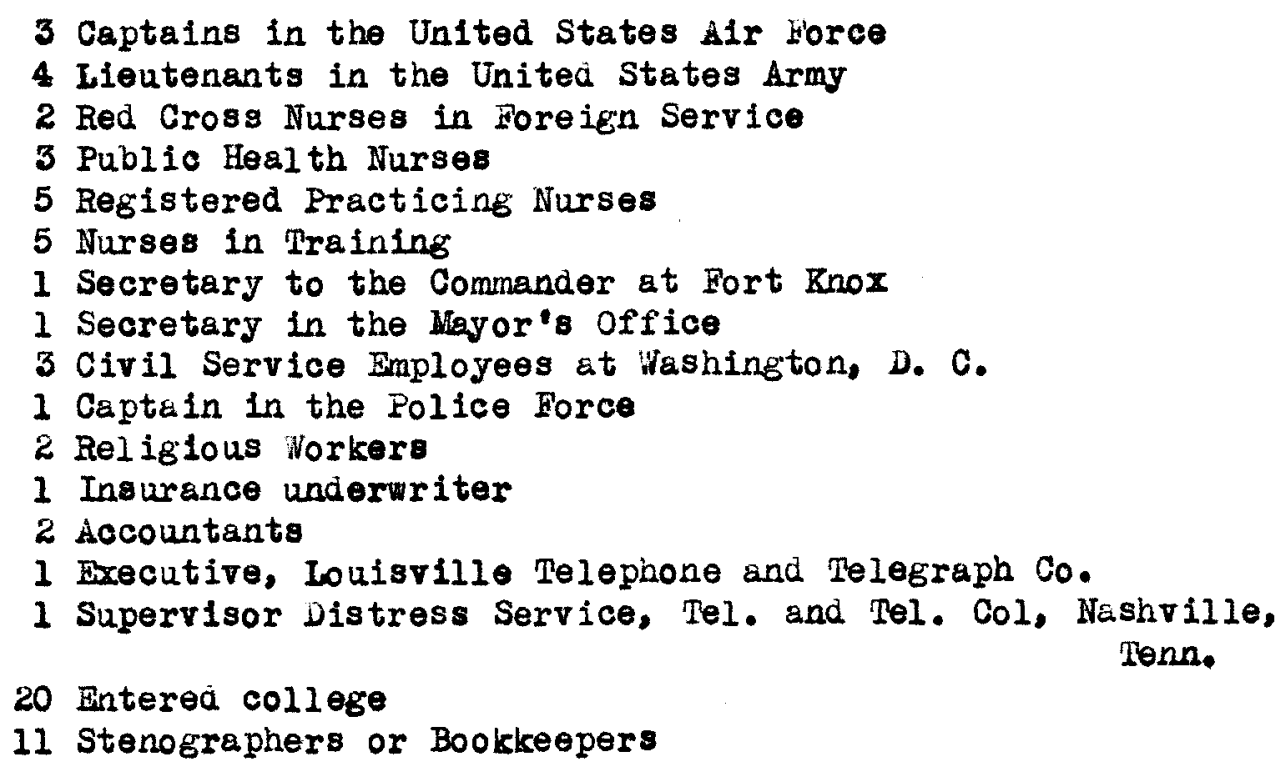

Wiss Virginia Sympson, secretary for the association, reports that there are a number of the graduates working in defense plants. 14

14 Permanent Records of the Alumni Association, idult Education High School 
Growth of the Curriculum. As the school grew in attendance and interest the curriculum grew; the original pattern enlarged to six fields. These changes are shown in Table V. Pages 5 land 52.

Summary of the Work of the Adult Education High School, WPA Pro-

gram. In summarizing the work of the Adult High School conducted by the Horks Progress Association, the writer offers the following table wich shows the enrollment by terms; the number of gradustes; and the average afe of those who attenade

\section{TABLEVI}

Summary of Enrollment in Louisville Adult Education High School $1936-1943$

\begin{tabular}{lccccccc}
\hline & $\begin{array}{l}\text { First } \\
\text { Semester }\end{array}$ & $\begin{array}{l}\text { Second } \\
\text { Semester }\end{array}$ & $\begin{array}{l}\text { Summer } \\
\text { School }\end{array}$ & Dotal & $\begin{array}{c}\text { Number } \\
\text { Graquating }\end{array}$ & $\begin{array}{c}\text { Average } \\
\text { Age }\end{array}$ \\
\hline $1936-1937$ & 27 & 54 & None & 81 & None & 28 \\
$1937-1938$ & 110 & 190 & 76 & 376 & 6 & 28 \\
$1938-1939$ & 355 & 427 & 156 & 938 & 18 & 27 \\
$1939-1940$ & 449 & 496 & 177 & 1124 & 34 & 24 \\
$1940-1941$ & 499 & 527 & 225 & 1251 & 55 & 22 \\
$1941-1942$ & 379 & 390 & 198 & 967 & 43 & 21 \\
$1942-1943$ & 440 & 392 & No & School 867 & 50 & 21 \\
\hline Totals & 2259 & 2478 & 832 & 5569 & 176 & 24 \\
\hline
\end{tabular}

The table above does not include the elementary classes, which enrolled a total of 216. This averaged 28 per year. There were 99 
Adult Education High School Anrollment

by Classes - 1942-1943

First Semester

Second Semester

English Department

\begin{tabular}{ll} 
Fnglish I & 48 \\
Fnglish III & 45 \\
Engl ish V & 35 \\
Fngl ish VII & 33 \\
Public Speaking & 30 \\
Vocabulary & 30 \\
\hline
\end{tabular}

Total 216
Finglish II $\quad 45$

English IV 46

Inglish VI 35

English VIII 44

Public Speaking

2 Discussion

Forum 55

Vocabulary 35

Total 260

\section{$\underline{\text { Language8 }}$}

Lat in I

25

11

Latin III

10

Total

46
Latin II

Spanish I

French II

Total
20

25

10

55

Social Sciences

Social Studies 35

World History 30

U.S. History 38

Anerican Govt. 35

Iatin-Am. Hist. 20

El. Economics 20

Economic Geog. 20

Citizenship for

Foreign-born 45
Social Studies 33

World History 30

U.S. History 35

Am. Govt. II 35

Lat in-Am. Hist. $\quad 20$

El. Economics 20

Economic Geog. 20

Citizenship for

Foreign-born $\quad 45$ 
TABLE Y (Continued)

Pirst Semester

Second Semester

Natural Sciences

General Science 20

Biology I 22

Physiography $\quad 15$

Heal th Science 15

Parent Ed. \&

Home Narsing 20

Total 92 \begin{tabular}{ll} 
General Science & 20 \\
Biology II & 15 \\
Physiography & 12 \\
Health Science & 12 \\
First Aid (ifen & \\
\multicolumn{1}{r}{ only) } & 20 \\
\hline
\end{tabular}

Total

79

\section{Hathematics}

General Wath. I 48

Algebra I 30

Algebra II 20

Trigonometry 10

Geometry I 25

Pre-Aviation

insthematics 75

General Wath. II 45

Algebra II 30

Algebra III $\quad 14$

Algebra I 20

Geometry II 20

Pre-Aviation

Hematics

Total 208

Total

174

\section{Commercial}

\begin{tabular}{lrrr} 
Shorthand & 38 & Typing & 72 \\
Ad. Shorthand & 25 & Shorthand & 35 \\
\cline { 2 - 4 } & 63 & Total & 107
\end{tabular}

Class Enrollment ....868

Class inrollment .....913

Individual Enrollment 440

Áv. No. classes ....... 98

Grades 1-4) Ele- 22

Grades 5-8) mentary 30

Indiviaual Enroliment 392

Av. No. classes ...... 2.34

Grades $1-4$ | Ele- 10

Grades 5-8) mentary 30 
who completed grade 8. The table does not include the business education classes from 1938 to September 1942. (Seo Page 50) There were 450 enrolled in that department.

WPA Adult High School Closed April 1, 1943. Before the WPA Adult High School closed an appeal was made to Superintencent Zenos Scott and the Board of Education of the Louisville Public Schools, through the clubs, the newspapers and the public in general, to continue the services it was rendering. At the Harch meeting of the Board of Education, a representative of the Louisville league of Women Voters, Mrs. Hillam Ladd, Chairman of the Committee on Education, made an appeal for the continuation of the school. Mirs. Ladd stated that from time to time members of the league had visited the school and observed its work; and that they highly approved the services which it rencered to Loulsville citizens and strongly recommended its continuation as a permanent part of the Public School System.

The requests were considered and the school was continued from April 1, until the end of the semester June 4, 1943. The salaries were paid from the Public School fund, and the school was permitted to continue without interruption antil the close of the semester. This action was greatly appreciated by those who were attending, since it enabled them to get the credit for that term's work. The fifty members of the senior class who planned to graduate were especially happy. 
Throughout the months of June and July many interested citizens, as well as the student body and faculty were anxiously awaiting Bome definite action from the Board of Education. Appeals were made by telephone calls, letters, newspaper articles, and a radio address about the need for this service in Louisville. Perhapo some excerpts from newspaper articles and letters might be appropriate here. The first is from the Louisville Courier-Journal Point of View Column, June 19, 1943. 15

There is an educational activity which I hope will be continued even though the WPA has withdrawn its financial support. This is the Adult High School which has been carried on at the Monsarrat School, Fifth and York, in order that the adults who worked during the day might have the privilege of getting a high school education at night.

No one can question the good this school has done who has seen how eagerly these adults have grasped the opportunity of finishing their high school work. A book could be written filled with human interest stories about the individual students whose ages ranged from teen age to grana-mothers. I remember attending the graciuatine exercises at the Christian Church and how inspiring it as to see these students, some of them wite-haired, come forward so proudly for their diplomes:

It was my privilege to attend this school one winter in order to take public speakins. Across from me sat a newaboy and on the other side man aoout sixty years old. Ambition knows no age.

I feel sure that the Board of Education will continue to meet this need by supporting such a worth-while effort.

Signed,

Emily Vaught, Secretary to:

Mir. F.G. Burdorf

15 Newspaper Article: Iouisville Courier-Journal, June 19, 1943 
The next is a copy of a letter to Dr. Zenos Scott about the continuation of the UPA Adult High School. 16 It is very interesting because it refers to the Night School at Finzer and Broadway, 1886-1891, which has been mentioned in Table II, page 14, of this study.

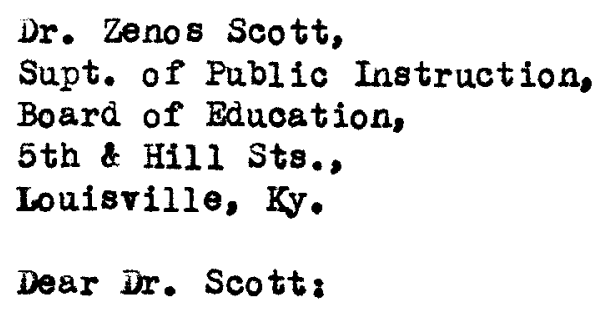

Years ago there was a night high school at Finzer on Broadway, and an olö, old friend of mine, Mrs. K. E. Robinson, was Principal. She used to talk of so many of her former pupils. There was Tred Diehl, now an Official of the Liberty Bank, Joe Haury, now an Official of the Todd-Donnigan Iron Co. There were the three Klingman boys; George and John were Ministers and Fred a Bank Accountant, the two Hiltons, one of them, I believe, is now Head of the Christian Church Widows and Orphans Home. There was George King, who became Head of the King Extraction Co. at San Francisco, Peter Meyer now a Plumber, Vim. Balke, Head of the Balke Iron Co., George Sutherland, Ifr. Volkerding, and a number of other names of men who have passed on, or I have forgotten, but they all felt they owed their success in life to the help and encouragement that they had received in night high school.

In Mr. Nicholas Finzer's lifetime, he was an ardent supporter of this particular school effort.

16 Letter: Addressed to Dr. Zenos Scott, Superintendent of Louisville Public Schools, June 1943, from Miss Florence Housewald, Superintendent of Public Health Nursing in Louisville. (A copy of this letter was sent by Miss Housewald to the writer of this thesis.) 
I bave the same appreciation and admiration for Mrs. Flora Morris, as I had for Mrs. K. E. Robinson, because they are alike in their ability to encourage and inspire those who are attempting, in adult life, to make up high school education.

With a deep appreciation of the past and present work of this night high school, and looking toward the future, I feel that it is farsighted for the Board of Education to again sponsor a night high school.

Wishing you continued success,

\section{Sincerely yours, \\ Florence L. Housewald}

Monsarrat School Building Closed. In the report of the Louisville Public School Survey, it was recommended that Wonsarrat School be closed and that the 348 junior high school pupils of Ibnarrat Day School be accomnodated in other junior high schools. 17 The recommendation included: "the school should be abandonea and the building razed." The recommendation was carried out and al though the building was not razed, it was abandoned June 30, 1943. That was a great disappointment to the students of the night school because they had learned to love it. It was conveniently located anà when lighted at night it had a welcome atmosphere.

The Firgt Hope of Reopening. The question of continuation of the Adult Night High School was under consideration by the Board of Edacation throughout the entire summer.

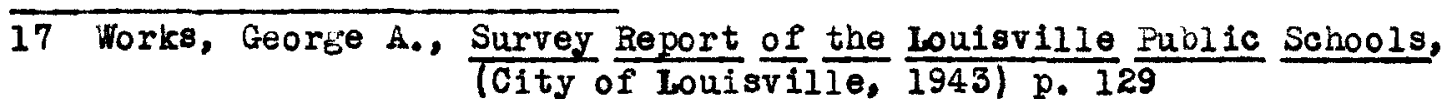


Many people telephoned the writer, who could give them no reassurance that the school would continue. A number of the teachers who had helped to build the WPA School found it necessary to take other kinds of teaching, in order to assure themselves of work. Three of the teachers went to Jefferson County High Schools; one to the Louisville Public Schools; and two changed to other kinds of work. The writer went to Wayne, Michigan to teach in the Community Center School.

Finally a newspaper article appeared which brought hope to many who were eagerly watching the papers. 18

\section{Adult School Opening Goal}

Louisville Adult High School, closed when WPA funds for its support were no longer available, probably will be re-opened in October, Stuart C. Campbell, president of the Board of Education, said today.

Monsarrat School Bullding, which formerly housed it, has been closed", said Mr. Campbell, "but I am confident we will find a new place and funds to carry on. It probably will re-open in october."

The chairman sald that Zenos B. Scott, city school superintendent, "is compiling all information on the matter and will submit it to the board at a September 7 meeting when some definite action 111 be taken."

Urging re-opening of the school, an alumnt committee of the institution wrote Mr. Scott: We believe that the educational leaders of Louisville deem it sufficiently important to continue this work, which has become so vital in the life of our community. We feel that our ability to understand something of the trend of concerted effort today

18 Hewspaper Article: Louisville Times, September 1, 1943. 


\footnotetext{
"was gained by our attendance at Louisville Adult High School and we sincerely hope that the same opportunity ill be given those who heve not as yet completed high school and are anxiously awaiting reopening of the school."
}

The committee acded that about 5,000 persons have attended the school with the average semester enrollment being 400 to 500. The group's "full and earnest cooperation" was promised in seeking the reopening.

Beginning of The Adult High School Under The Board of Equaction.

It wa decided at the September meetlag of the Louisville board of Education to continue the services of adult education by establishing an Adult Night High School at Ahrens Trade School. At that meeting:

Dr. Zenos Scott reviewed the history of adult education in the louisville public school system from the time of the stoppase of so-called erenine classes in 1932 until the board this year appropriated sufficient funds to continue until the end of the term the adult education school operated by the works Progress maministration.

Scott recommended "very earnestly" that operation of adult education schools be incorporated in the board's current program. As adopted, the plan is to have classes from two to four nients a week, probably for about three hours a night, at the schools selected. For non-residents charges will be on the same basis as in day schools.

Pleasure at the action of the board in voting establishment of these schools was expressed by hrs. S. T. Greenbaum, president, and Mrs. William W. Ladd, chairman of the education committee of the Louisvilie League of Women Voters. 19

Miss Ethel Lovell, Principal of Ahrens Trade High School, was appointed principal of the Night High School also. The writer, who 
had been principal of the MPA Adult High School, was called back from Michigan to be Assistant Principal. The faculty was composed largely of teachers from Miss Lovell's faculty of the Ahrens Day High School. They were: Miss Harguerite Arnold, science; Hr. Howard Robey, english; irr. James I. Smith, economica; Hiss Alice Corwin, suglish and literature; Mr. Jumes Distler, mathematics; Mr. C. B. Burkhead, mathematics; Mrs. anna M. Garrico, history and citizenship; Miss Monta Rae Iunstall, Finglish and elementary sabjects; and iss velazine Hardin, history and typewriting. Mr. Distler was a memider of the faculty of Manual iraining righ School. Three of the teachers who had taught in the HPA High School were Mrs. Carrico, two years; Miss Hardin, one year; and Miss Tunstall, one semester. All of these teachers excepting the last three named taught full time in their respective day high schools; they took the work of the Night High School two evenings per week in addition to their regular work.

Organization of the Ahrens Night High School. The Adult Night High School at Ahrens Trade School opened September 27, 1943. The following article appeared in the Louisville Times the afternoon of September 29: 20

A total of 299 persons have registered for Adult Night School at Ahrens Trade School and 108 at Central Colored High, Ir. J. K. Long, assistant superintendent of city schools, said today. Classes for those who have registered start at 6 p.m.

$\overline{20}$ New8peper Article: Louisville Times, September 29, 1943 
today, but registration will continue from 6 p.m. until 10 p.m. through Weanesday.

Classes were scheduled to meet four evenings per week, 6 to 8 $0^{\prime c l o c k}$ and 8 to $100^{\prime c l o c k . ~ N o ~ c l a s s e s ~ w e r e ~ s c h e d u l e d ~ f o r ~ M o n-~}$ day evenings, for the convenience of workers in war industry and in department stores which were open on londay evenings. Business education classes were scheduled on Tuesdays and Thursdays from 6 P.M. to 8 P.M. Americanization classes were scheduled for foreign-born persons on Wednesdays and Fridays, 6 P.M. to 10 P.M.

The regular high school curriculum included English; three social science courses; three courses in mathematics; a general science unit; and a major in business education including typing, shorthand, bookkeeping and comptometry. In addition there were apprenticeship courses such as radio maintenance, plumbing, sheet metal, machine shop and woodwork. there were a total of 686 persons enrolled during the first term. Approximately 50 per cent of the registrants were above 19 years of age.

During October, the high school department, which had an enrollment of 381, was reported to the Kentucky State Department of Education for rating as an accredited high school. Daring the second semester the school was notified that its rating was Class A. Thus it became the first accredited night high school to be conducted under the auspices of the Louisville Public Schools.

The students were very much in earnest and seemed to enjoy the work. Many comments were heard about the beautiful and comfortable school. 
Some of those who were enrolled in full time high school work found thet regular attendance four evenings per week was difficult because they often had to work overtime to speed ap war industry. They were advised to carry only two or three subjects. The attendance in some of the classes became rather poor however, liss Lovell said that she was not discouraged, since that was the condition tinroughout the United States.

The business department was one of the attractive phases of the night school. Its enrollment as nearly 200. Perhaps one of the happiest groups of students was the class of foreign-born persons who were preparing to become American citizens. They enjoyed the friendly atmosphere which the teacher, Ars. Anna Carrico, created in the classroom. Thirty-four members of this class were granted United States citizenship February 18, 1944. 21 Another interesting phase of the work was the use of visual education to supplement the work of the general science and inglish classes. The opportunities offered by the Ahrens Night High School for the first year were greatly appreciated. There were ten persons who completed the high school course and were granted diplomas June 1, 1944. The graduation exercises were held in the gymnasiumauditorium of the school. This school has many possibilities for 21 Jew 8paper Articles: Louisville Courier-Journal, Feb. 13, 1944 
a broader prostam of adult education and service to the city of Louisville. Certainly the Louisville School Board should be praised for making it possible. 
ADULT BDUCATION UNDER PUBLIC SCHOOL SYSTHWS OF SONE OTHER CITIES

Back in 1931, Dr. Fred Finglehart in his book Pablic School Administration said:

"The public schools in general were slow in developing interest in programs of adult education, principaliy because they were afraid to involve themselves in additional expense. Even in some of the more progressive cities the programs were meager and poorls supported, al though facilities for adult education could be pro$v i d e d$ economically in the evening hours when the regular day school is not in session. 1

Attitudes change. If a survey were made of what has been done in some of our progressive school systems today, it would very probably reveal great strides which have been made within a fow years' time. Certainly today e find many professional educators who have caught the spark of enthusiasm and are encouraging the organization of adult education centers. Perhaps it would be well to look at the accomplishments of a few of the schools for the training of adults, which are supported by public school systems. A survey of what has been done in general, even in cities the size of Louisville is far too broad for this study. Therefore, the writer has chosen three cities which possess phases of adult education which are striking in interest, and which could help to form patterns to improve the offerings to adults in Louisvilles (1) the

1 Fnglehart, Fred, Public School Adminlstration, (Ginn and Company, 1931) p. 531 
Opportunity School at Denver, Colorado; (2) the Sdult Iducation Center, at San Jose, California; and (3) the Public Adult Evening Schools, in Philadelphia, Pennsylvania.

The Opportunity School, Denver, Colorado. The Opportunity School was established in 1916 under the Board of Education when Mr. Carlos M. Cole was Superintendent of Schools. It was established largely through the vision and energy of Miss Emily Griffith. It began in September, 1916, in an old school building at Thirteenth and Welton Streets. At present it is housed in a beautiful new building which is used both day and night for adults. It has an annual attendance of 9,000 persons. 2

Sources of Support of The Opportunity School. It is financed by the public school system of Denver. The sources contributing to its support are: (1) district school taxes, (2) federal subventions under the Smith-Hughes Act, used in paying one-half the salary of instructors in vocational courses which conform to the requirements of the HCt, (3) state grants to match part of the Smith-Hughes subventions, (4) an apportionment from the State Permanent School Fund, (5) proceecs of the sales of products and services of industries carried on in the school shops, (6) gifts. 3

\footnotetext{
2 Swift, Fletcher $\mathrm{H}$. and Studebaker, John., What is This opportunity School, "American Association of Adult Bducation", New York, 1932. p. 10

3 Ibid.. p. 69
} 
The writer has chosen this school because its philosophy embodies the great understanding that, "Man must work and have maintenance which leads to security before he can enjoy the blessings of cultural Edvancement."

The administrative staff of the Opportunity School consists of two groups: (1) officials belonging to the central administrative staff of the Denver public school system; (2) officials directly attached to the school, headed by Miss Emily Griffith. The teaching staff consists of teachers especially trained to teach adults, or those who are likely to sympathize with the purposes and pollcies of the school. The teaching staff falls into two groups: (1) teachers of academic subjects; (2) teachers of special subjects including shop instructors. There are 57 teachers including clerks in the day adult high school, and 62 in the night adult school. ihiety-five of these teach adult classes in both the day and night schools.

Teachers of academic subjects are paid according to the regular single salary scale of venver. Some teachers of special subjects are on a permanent substitute salary of $\$ 5.50$ for five hours' work. Teachers of trade subjects receive a salary equivalent to that of a shop foreman. This averages about $\$ 200$ per year less than that receired by the teachers of academic suojects. 
The curriculum of Opportunity School. Approximately 73 per cent of the students at Opportunity School are pursuing trade or commercial courses. Nevertheless, the School is far from being merely a rocationel school, for it provides classes in general or academic subjects in its elementary and high school departments, classes for illiterates, and classes in citizensip. 4

Some classes, such as auto mechanics and beauty parlor training, admit only those preparing for or those already in a trade. Others, such as dress-making and cooking, admit on a broader basis. Certain classes run throughout the year, others only a few months or weeks. Every effort is mie to adjust a student's program to his personal schedule. The programs of some students must be arranged for a few hours a week, for alternate weeks, for al ternate dey and night classes, for eight hours of intensive work a day, for a few weeks or a few months. However, possibly 80 per cent of the students attend Opportunity School during only one year. This fact, combined with the fact that the enroliment from year to year is constant and tends to increase, furnishes an important measure of the educational value of the School. Students are quickly helped to accomplish their purposes and they urge their friends to seek the services which have helped them.

4 Swift, and Studebaker, op. cit., pp. 27, 32, 33 
Some of the Courses offered in Opportunity School. Many courses are offered in the following fielda: (1) commercial, (2) trades, (3) miscellaneous, and (4) academic.

Commercial courses taught include accounting; business arithmetic, Fnglish, and spelling; bookkeeping; commercial law; use of dictaphone; use of office machinery; office practice; salesmanship; shorthand; typewriting. Every student who takes shorthand, typing, or salesmanshlp, takes business finglish. If he is taking bookkeeping, he takes business arithmetic. There is a constant attempt to relate class work to the job for which it is a preparation. 5 Trade courses constituted 38 per cent of the attendance at opportunity School in 1930-31. Opportunity School claims to be the first public school in the United States to offer a course for beauty parlor operators. In adaition to theoretical and practical training, students receive instruction in appropriate personal care, manners, and ethics.

Welding Taught at Opportunity School. The combined enrollment in acetylene and electric welding in 1931 was 502, the largest of the trade courses offered for men. Vertical, horizontal, and overhead welding are taught. Welding processes range from acetylene welding through atomic arc, carbon arc, and atomic hydrogen welaing.

5 Swift, and Studebaker, op. cit., pp. 27, 32, 33 
Different jobs require different processes. Students at opportunity School are taught not only practical techniques but theory and many related sciences such as chemistry, physics, metallurgy, and mathematics. The course is divided into units. A student may take only one unit if he wishes. There are no less than 18 positions a welder can fill after he has completed a course at this school.

The automobile mechanios department undertakes every type of repair job. Instruction in starting, ignition and lightning is offered in night classes. Shop courses consist of jobs done by students under the immediate supervision of highly skilled instructors. Automobiles necessary for shop training are furnished by individual citirens and by dealers. 6

The writer will not try to describe the other trade courses which are offered, but will list: baking, bricklaying, plumbing, millinery, machine shops. 7

The academic classes in elementary subjects are angraded with emphasis upon the three "R's". They are taught in both the day and the night school for adults. Here are found people of every description, and ages varying from 16 to 78 . In school attainnents, most of these students range from the second to the eighth grade, although many former high school students, and many stenographers, come for training in English, spelling and other elementary subjects. 8

6, 7,8 Swift, and Studebaker, op. cit., pp. $34,38,40,41$ 
Opportunity School has a fully accredited high school. It provides no extra-curricular activities, but has the sane general curriculum and grants the same diploma as other Denver high schools. Its primary aim is to help mature students who lack high school edacation. These include: (1) individuals preparing to enter college; (2) draftsmen, engineers, and others who need high school training for advancement in their occupations; (3) parents who wish to keep up with, or to help, their chlldren; (4) high school greauates reviewing for examinations; (5) students sent from other high schools to make up work or to receive indiviaual attention. Brery teacher has two one-half hour periods in which to give pupils individual help. These, of course, are other than his or her regular class periods.

The miscellanoous courses which are of fered are: public speaking, lip reading, cooking, citizenship, and individual help for illiterates. 9

Wost of the thousanos of individuals who pass in and out of the doors of opportunity School year after year go there seeking either the fundamental preparation for some rocation, or supplementary training to increase their efficiency and earning power in the occupation they are already following. Although this is the first and basic reason for the existence of the school, the principal, assist-

9 Swift, and Studebaker, op. cit., pp. $34,38,40,41$ 
ant principal, and instructors seek constantly to develop through personal conference and class discussions other qualities which are quite as necessary as holding a job, regard for the rights of others, ability to cooperate, courtesy, right use of leisure time, personal appearance, builaing up of social attitudes and ideals, the creation and restoration of self-confioence, and respect for self and others.

Summary. The writer has chosen this center because the Opportunity school contributes something to the understanding of possibilities in Louisville. The idea that breadinners, when given a chance for vocational training, could be rehabilitated economically and spiritually. The Opportunity School has contributed to the economic, occupational, spcial, intellectual, ano moral needs of large numbers of persons in a prosperous and growing mid-western city. It is a tax supported institution and runs both day and night in a spacious building provided especially for adults. That is a dream which Louisville might consider a far distant hope.' At present ahrens Trade School is equipped to offer vocational opportunities to adults. Teachers of academic subjects are paid according to the regular single salary scale of Denver. That is an adjustment wich should be made in the employment of teachers in Louisville. It is one of the Important patterns which the Denver Opportunity School can furnish to Louisville. The writer especially likes the above paragraph which says "the principal, assistant principal, and instructors 
soek constantly the building up of social attitudes and idoals."

The Adult Education Center, San Jose, California. The Adult Education Center at Seventh and rernando Streets, San Jose, Californ1a, is conducted by the San Jose Public school system. It has been in operation fourteen years and now uses the juarter Perm plan. There were 56 yearly courses offered this pest school year; 17 special courses for the fall quarter only, 8 special courses for the winter quarter, and 6 special courses for the spring quarter. 10

There is a registration fee of $\$ 1.00$ per person, each term. This is for the whole institution and not for indiviaual classes, and admits a student to any and all classes and activities.

In California adult education is provided by law on a state-wide basis under the administration and supervision of local boards of education and local school authorities. Bxpenses incurred by local districts for this service are refunded by the state. Close supervision is maintained by the State jepartment of Education, and all courses have to be approved on the basis of education worth.

Adult education in California is organized as a separate field on equal status with other branches, and is administered as a phase of secondary equcation.

The curriculum is based on social ana cultural neods. The list of 10 Handbook, Adult Education in San Jose Public Schools, September, 1943. 
offerings seems quite up-to-date and very practical for that section of the country. We find listings of courses guch as the following:

I. THE SAT JOSE TORUM - discussions with a vital symposium on:

A. Bussia, Great Britain, and the United States

1. historical ains of each nation

2. the contribution of each to the coming victory

3. the post-war aims of each nation

4. the ability of all three to collaborate

This is the plan for the fall quarter. The winter quarter will consist of discussions of China and other nations involved in the struggle.

II. IHE SAN JOSE FORUM uncer the sponsorship of the Uhamber of Commerce will conduct the following discussions:
A. Can America Take $\frac{\text { Credle-to-Grave Security Plans? }}{\text { 1. }}$
2. the MRPB plan and Wagner Bill in America

III. WATIN AMERICA, "Land of Opportunity"

A. A course to foster sreater mutual understandins between the United States and Latin Amorica

1. Hall uuarter: Latin Anerica in Motion Pictures (two films shown at each meeting)

2. Winter Quarter: The Caribbean and Panama Canal Hotion Pictures

IV. COURSES IN COLOR - "Visual Rducation" 11

1. Fall warter: Appreciation of the West

2. Winter wuarter: Scanainavia then and Now

3. Spring uluarter: New York, Worla Netropolis

V. GIGISH - "The Wother Iongue"

1. English Workshop - The mechanics of the language

2. Creative witing - urocational

II F'ilms secured partly through University of valifornia and partly from government sources. 
V. ENGIISH - "The Wother consue" (continued)

3. Social Conversation - An art

4. Public Speaking - an increasing demand

5. Books - Book News and Review

6. Children's Literature - For parents

7. The use and enjoyment of the library

VI. SPANISH

1. Elementary - conversation and vocabulary a. Iat in American form - not the Castilian

2. Intermediate - grammar and writing

VII. PSYCHOLOGY OF PERSONALITY

1. Lall Quarter - Psychology of Haturity

2. Winter quarter - The Psychology of Individual Personality

3. Spring Quarter - Psychology of Emotions

VIII. FINE ARTS ${ }^{6}$ - Appreciation and Applied

1. Everjàa art appreciation

2. uraphic arts

3. Applied arts - in the home

4. Plastic arts

5. 解sic appreciation

6. Choral work

7. Instrumental Music

8. Drama

9. Photography

IX. TRAINING FOR COMAETRCE AND OFFICE

1. Bookkeeping Hade Basy

2. Office Machines and Machine Calculation

3. Secretarial Practices

X. HOME LIFE - "Women Keep Civilization in Business"

1. Family Finance "Children Have First Friority"

2. Child Psychology

3. Adolescent Pgychology

4. Home Haintenance

XI. WHEN JOHNNY CONES MARCHIVG HOMT AGAIN!

Courses to be supplied when they are needed for returned service men and women.

12 Handbook, Community Art Center, "Studio Appreciation Courses in art, irusic, and vrana" San Jose Public Schools, June 1944 
The Adult Center is planning to meet its responsibilities in the period of demobilization, and because an adult education center has the fluidity which permits it to establish whole systems to meet new situations, as they arise, it will have ready in time what is needed by a majority of the demobilized personnel: 13
(a) retraining for new positions
(b) guidance and placement courses
(c) educational opportunities to complete high school and junior college
(d) retraining and reorientation for temporary workers replaced by men returning to their permanent jobs

The writer has chosen to give the outline listing some of the courses offered in the San Jose Adult Bducation Center because they embody civie and social understandings which are extremely vital to the culture of the time in wich we live. Such an outline of courses furnishes a pattern which would enrich the program of offerings in Loulsville. A good forum is greatly needed. Our city has many social problems wich should be brought to the attention of all citizens and a public discussion forum is an excellent way to do this. The writer also likes the San Jose Art Classes. They furnish an opportunity to adults to grow in the appreciation of cultural values, and provide both vocational training and avocational interest. Ahrens Trade Night High School could offer some of them, for there are good art rooms at Ahrens. The courses in "Visual Education" are up-to-date and could 
set an excellent usable pattern. Ahrons Trade School has a dark room

and a projector wich is used by the Adult Night High School.

The Public Adult Evening Schools, Philadelphia, Pennsylvania. The state of Pennsylvania has long been adult education conscious. In a balletin, The Public Adult Erening Schools of Philadelphia, we find the following letter by Alexander J. Stodiard, Superintendent of Schools: 14

To The Out-of-School Youth and Adults of Philadelphia:

With the tempo of war steadily increasing, there is a growing need for opportunities for basic ano supplementary training for young and old. Workers should take time out for relaxation and recreation if they are to render maximum service to their country on the production front. Your schools are playing their part in the war effort in offering, through the acult education and recreation programs, many opportunities for men and women (1) to acquire new skills and knowledge, (2) to increase existing capabilities, as well as (3) to afford opportunities to all for relaxation through informal recreation prograns or in the pursuit of hobbies.

The needs of the home front are being met by the schools in affording opportunities to all to participate in the Town Meetings sponsored jointly by the School District of Philadelphia and the Foreign Policy Association. These programs serve to acquaint us better with many of the factors underlying the world conflict in which we are engaged.

The problems confrontine parents today are many and complex. In response to numerous requests we are furnishing leaders for discussion groups, composed of parents who wish to meet together and, through exchange of experiences and ideas, understand more fully how to solve problems arising in their homes and communities.

This adult school system strives to be flexiole to the end that it will best serve the neeas of the community. We welcome sussestions from inaividuals and civic groups that will assist us in achieving our purpose to serve you to the extent of our ability.

14 Bulletin: The Public Evening Schools of Philadelphia, Board of bducation, vivision of school hension, Parkway and lwentyfirst streets, Philadelphia, Pennsylvania, 1943-1944. 
The writer quotes this letter because it expresses her philosophy of adult education mainly in that:

1. It must keep pace with the tempo of the times

2. it must aid in understanding netional and foreign policies

3. It must lead in solving home and community problems

4. It must be flexible and democratic

The work of adult education in Philadelphis is not confined to one school or center, but fifteen different schools are open during the evenings to men and women.

The Standard High School course for adults begins September 8 and 9; commercial, distributive education, technical ana other formal courses begin September 20 ana 21 ; recreation and hobby courses befin at the same time, but registrations are acceptea at any time so long as accomnodations are available. In addition to the initial registration, persons may enter for trade extension or technical course8, and home Iife courses October 25, 26, 27; January 3, 4, 5; and February 7, 8, 9. This section of the evening school is divided into four quarters of approximately $s$ ix weeks each.

The Schools are free. The classes are conducted by the School District of Philadelphia. Persons, not residents of Philadelphia, may enroll in the evening school upon payment of a tuition fee of $\$ 10.00$ per term for one course; $\$ 15.00$ for two courses; $\$ 20.00$ for three courses; and $\$ 25.00$ for four courses. 
The program consists of classes in: (1) General Education; (2)

Citizenship; (3) Technical Courses; (4) The Standard Ivening

High School; (5) Arts and Crafts; (6) Home Haking; (7) Recrea-

tion; (8) Distributive Education; (9) Commercial Education; and

(10) In cooperation with the Wanamak Institate: a. Parent Dis-

cuasion Groups, b. Town Neetinge, c. Film forums, d. Symphony

Orchestra, $\theta$. Junior Town weeting on the Air.

Standard High School. The Standard Brening High Schools of Philadelphia is organized for service to several groups of students who need the usual high school subjects, and for other specialized purposes as follows:

1. Pre-high school students, those who have not finished the first eight grades, have an opportunity to complete their preparation for high $\mathrm{school}$ in the High School Preparation course.

2. Students who have not as yet finished an accredited high school course leading to a high school diploma, for admission to college, or to meet pre-professional requirements of the State jepartment of Pablic Instruction, or to meet the requirements for business advancement.

3. Day school students who need not more than two or three subjects to meet the graduation requirements of their respective day schools for a diploma. These sibjects must be completed witin one school year after the student leaves the day 8 chool if he desires to graduate from the day school. These are called Parent-Scinool Students.

4. Graduates of day schools who need college entrance units or who need additional mathematics or science courses for technical advancement or army requirements. These are called Graduates.

5. Students with particular interests in inglish iuterature (Contemporary irama, Poetry, Philogy, Plays of shakespeare): advanced Composition (Broadcast scripts, motion picture 
scripts, short story, magazine articles); irt Appreciation and the Philosophic Background of aesthetics; Spanish or French Conversation. These are called bxtension students.

6. In addition to the above, there are certain specialized, nonstandard courses including Chinese, Iip reading, and Speech Improvement.

The Philadelphia Standard Evening High School are held four nights weekly, the classes meting alternately Monday and Wednesday, or Iuesday and Thurgday from september 8 to June. The adult attitude of teacher and student dominates the classroom procedure and administrative leadership.

Student participation in the government of the school is a big factor in its success and serves to make the newcomer feel comfortable. It gives opportunity for student leadership in a practical and forceful way. The social life of the school is carefully guided by the Student Senate, which publishes a monthly paper "The Bvening Star", carries on athletic prosrams, conaucts assemblies, sponsors school dances and generally assists in the smooth operation of school administration.

This school meets genuine community need for the more formal type of education leadine to a particular objective -- a high school diploma. Despite the condition of the times 3000 students registerod last term and considering the necessity of military service or defense activity, they maintained a remarkable recora of attendance and achievement. 
The curriculum offered by the Standara Evening High Schools of Philadelphia can furnish information, and a definite zoal for the Louisville Adult Night High School. The kinds of service which it offers to various types of student; the variety of courses offered; and the democratic procecure of student participation all appeal to the writer.

Summary of the Chapter. Bach of the adult education centers reviewed in this chapter offers something of definite interest for the program in Louisville. The Opportunity School of Denver offers patterns for vocational training and indiviaual guidance, and its regular schedule of a single salary scale for the staff is needeci in Louisville. The San Jose Adult Education Center offers the pattern for an excelient forum for the study of local, state, and world problems in social, civic and economic fields. Louisville needs such a forum. The Philadelphia Standard Evening High Schools offer many sugsestions which if followec would enrich the program which is offered in Louisville. 


\section{CHAPTER IV \\ POSSIBIUITIES FOR SERVICE IN LOUISVILIN \\ THROUGH ADULT HDUCATION TODAY}

For the past three years the emphasis in adult education has been on a "Traininf for War Program". Today, al though the war is not as yet won, we must turn our attention to a "Training For Readjustment to Peace Time Activities Program". The returning veterans are filtering back and war industries are turning attention toward peace-time production; therefore, perhaps the most timely consideration in adult education service is a:

Counselling Service and Retraining Program

1. For the returning personnel of the armed forces

2. Hor the readjustment and retraining of war workers

3. For assistance to the homefront worker whose job has remained static

4. For morale building and assistance to those who are emotionally strained

5. For quick anō wholesome plans for relaxation and recreation

One way to expedite such a plan would be the formation of a council composed of representatives of each organization which conducts a program of adult education, to work in conjunction with representatives of the Veterans Bureau. The Veteraws. Bureau has an active program of counselling, and the agencies which attempt to furnish training for returned veterans would be better able to serve if there were a co-ordinating agency, such as the above mentioned coun- 
c1l. Also, the publication of circulars or pamphlets which interpret opportunlties available. Community councils for adult education are advocated by the American Association of Adult Education. 1

Rehabilitation Program. The part which an adult education school or center can play in this "Rehabilitation Program" is vital because general education is the foundation for required anderstandings in all training or development. an adult must have the tools of learning before he can advance either vocationally or socially. Hence, there should be carefully planned and specific programs of basic training for improved scholarship from the level at which an adult stucient finds himself.

A program for training or retraining adults should include the following major considerations:
1. General Education
2. Vocational Training
3. Civic and Social Understandings
4. Recreational Opportunities

General Education. General education courses should be planned to advance the learning of adults of any grade level. There should be elementary schooling for adults to enter high school; for adults who are functionally illiterate; and for adults who need refreshment in some part of the elementary course.

1 Community Councils In Action: Journal of Adult Bducation, (American Association for Adult Education, New York, 1941) 
Standard idult H1gh School. There should be an establisheci and standard high school for adults ho desire to have some measurement of educational achievement; for those who desire high school training to aid in fuller and more satisfactory living; and for those who wish to standardize credits for college entrance. Vocational Training. One of the first considerations for a program of adult education is the development of skills and understandings for earning a living. Without means of livelihood no man can be happy or independent enough to enjoy cultural pursuits. Therefore, of paramount importance is a program to develop skills and understandings, for those who desire a specific rocation such as: business equcation; distributive training (selling); trado extension courses; or technical training. Civic and Social Understandings. Closely allied with the programs of rocational training and an integral part of an academic prosram of adult education is the study of "Civic and Social Affairs". Such a program is fundamental to the general welfare of the whole nation. Such a program should be planned for responsible citizenship; for local interest and inprovement; for civic cooperation; for improvement in "The Anerican Way of Life"; for citizenship training for the foreign-born; for safeguarding the family as a unit basic to our culture; for the ideals of socially acceptable conduct; for religious and social welfare; for better cooperation with the postwar world; and for the simple needs necessary for "living with one another". 
The incyclopedia of Educational Research fives the following statement which seems pertinent here:

The adult who wishes to anderstand the modern world and to obtain impartial and accurate knowledge of citizenship, of facts of social importance necessary to effective behavior as a citizen and as a fully developed normal person, is usually poorly guided and ill served. There are not enough courses in the social sciences; coverage by forums and discussion groups is thin and ineffective. Bven "cultural" opportunities are not easily accessible to large groups of citizens, moreover, the offerings are personal rather than social and are marred by duplication and confusion of purposes. Opportunity to establish social contacts and to escape from monotony would seem to be widespread in modern urbanized society, but there is much evidence of unsatisfied need especially for assistance in developing personal ability to engage in social life.

Social Activities and iecreation. One of the major considerations for service through adult education is a program of wholesome social activities and recreation. This should be planned for the returned veteran; for the tired war worker; for the emotionally strained; for the lonely individuel; for the average citizen.

What Can Be Done in Programs Such as Those Mentioned Above. The elementary department of a school for adults should not be graded too strictly. Wany persons who have not completed the grade school but whose minds have been matured through life's experiences could be given short orientation courses to establish the use of the fundamental tool subjects. In a comparatively short time, they will be able to pass standardized tests for high school entrance. Those

2 Bittner, W. S., $\frac{\text { Adult Edacation, Fncyclopedia of }}{\text { search, 1940. p. }}$. 25 cational Re- 
who are classified in the miade grades -- perhaps the fourth grade through the sixth -- should be given much practice in oral reading; in simple understandings of correct spoken Bnglish; letter writing and simple written forms which they can use in daily contacts; history, geography, literature, scientific inventions, and news of the changing world are all incliaged in the reading materials which are now especially prepared for adult elementary classes. Those who are total illiterates can be taught to read, write, and use the fundamental comoinations of arithmetic. The above simple learnings can help individuals to become better citizens by the psychological process of being accepted in the world in which they live. They will gain some of the needed selfrespect which is required to meot the difficulties of daily living. Methods used with adults in the elementary levels are varied. They respond quickly to the "individual interest" plan, in which an indiviaual advances as rapidly as he can through his own interest; they also like the "socialized group plan", in which a group of several persons of the same level work together and share ideas and materials.

What Can Be Done in a Standard High School for Adults. The of ferings of a standard high school course are somewhat determined by the requirements set by state law. In Kentucky these are very few: sixteen units, three of which must be in snglish, and one in American history. In Louisville, major anà minor fields for stuảy must be 
chosen, at least one subject other than English must be pursued three years, and at least two subjects must be pursued two years. That allows a choice of subjects which appeal to the individual student. The following is a suggestion of courses which could be made avallable in various high school fielda:

Einflish - written and spoken gramnar, word study, composition, creative writing, journalism, effective speech, public speaking, interpretive reading, dramatics, speech improvement for defective speakers, lip reading for the deafened

Literature - prose writinss, poetry, short story, novel, essay, editorial, current iterature, American literature, English literature, literature of early civilizations

Mathematics - general mathematical practices, business arithmetic, algeora, plane geometry, bookkeeping

Social Sciences - history (American required) World, European, English, illodern; government, economics, sociology, current event discussion groups, Americanization for foreign-born 3

Science - biological and physical, general science (introductive) health education, physiology and hygiene, biology, physics, chemistry (elementary), physiography

Foreign Languages - Spanish, French, Russian, Latin or Italian

Fine Arts - music appreciation, choral singing, art appreciation, applied arts, handicrafts, interior decorating, costume design, and window äressing. 4

Forum-Public Discussion Groups - economic problems, social problems, civic problems, trade and travel (visual education applied), foreign affairs, good-neighbor policy

3 Function of Liv Ing, "Education for Victory Journal", July 20, 1944 p. 19

4 Community Art, "Department of Adult Education" (San Jose Public Schools, San Jose, California, 1944) 
(with use of screen and projector), family life discussions.6

Vocational courses which could be offered. Adult education

courses can be offered to men and women returning to civilian pursuits, who need to learn new skills and understandings. ${ }^{7}$ The following outline shows rocational courses and the academic courses necessary for understandings needed by workers in these fields:

A. Commercial Education:

1. shorthand and typewriting

2. duplicating machine operation

3. calculating machine operation

4. bookkeeping for small store owners and clerks

5. bookkeeping machine opera-

6. accounting

7. commercial correspondence

8. office practice

9. commercial $1 \mathrm{am}$

10. commercial geography

11. income tax computation

B. Diatributive Education (Seling):

1. retailing

2. salesmanship

3. retail merchandising

4. window and counter display

5. marketing

6. retail meat cutting and

7. food products study
Related Academic Understandings

English, spolling

general mathematics

democracy

economics

social relationships - ethics

Related Academic Understandings:

English (reading, spelling, speech)

arithmetic

social relationships - ethics

democracy

economics

7 Debatin, Frank M., Administration of kdult Education, pp. 425-429

6 How to Organize School-administered Forums, Forum Planning Hanäbook, (American Association for Adult Educetion) pp. $50-59$ 
C. Prade Preparatory:

1. automobile mechanica

2. blueprint reading

3. cabinet making

4. commercial art

5. dress design and

draping

6. electrical construction

7. machino shop practice

8. mechanical and architectural drawing

9. radio, and radio code practice

10. general woodwork

D. Trade Pxtension:

1. blueprint reading

2. drafting - architectural

3. electroplating

4. optical mechanics

5. petroleum refining

6. plumbing

7. power plant engineering

8. printing - hand composition, layout, presswork, linotype

9. tailoring

10. textiles - fabric analysis and design, chemistry, fabric testing

11. watch repairing

12. beauty culture

13. barbering

14. pattern makins

15. plastice
Related Academic Courses:

mathematics

reading, spelling

democracy

electricity

Related Academic Courses:

Finglish (reading and spelling)

mathemat 108

democracy

economics

electricity

In the above outline of commercial courses there are the popular courses which are in demand for stenographers and office workers to learn new skills, and the refresher courses for those who desire to bring old learned skills up-to-date. Phere are the courses in calculating and duplicating machine operation, as well as general office 
practice and the cultural and social understandings neeced by those employed in office work.

In the field of "distributive education" there are the courses needed by persons who work in stores; who represent wholesale firms as salesmen; who operate stores; and in general those who act as distributors between the producers and the consumers.

The "trade preparatory courses" are for those who have had no experience in industry or trade, for instance, in automobile mechanics there is practical and related instruction covering electricity, power plants, oiling and cooling systems, transmissions, universals, rears, brakes and frames. In "woodwork" there is the study of varLous woods, and how to finish new wood and to restore old pieces. The "trade extension" courses are for those who are employed in a particular trade or industrial pursuit. They are planned to supplement understandings and practices already in use.

The above-listed courses are suggestive for all persons interested in vocational preparation.

Groups for Civic and Social Understandings. Classes in Family Life and Home-improvement can be organized for all who feel the problems of modern family life to be a part of the complicated existence of today. Such a course can strengthen the ideal of the family as a unit; 
the heritage and normal growth of chlldren; and the understandings of socially acceptable conduct. It can be made very interesting by discussion groups of parents and prospective parents who seek to understand the solution to problems which arise in their homes and communities. President Roosevelt at the Wite House Conference on Children in a Democracy, 1939, said:

We make the assumption that a happy child should live in a home where he w1ll find warmth and food and affection; that his parents will take care of him should he fall 1ll; that at school he will find the teachers and tools needed for an education; that when he grows ap there will be a job for him and that he will some day establish his own home." 8

Classes in an adult education school or center could be formed to consider questions of home-making. They can be motivated by the groups themselves. Perhaps some of the following subjects might be sugsested as of interest: child care; child psychology; adolescent psychology; nutrition; first aid or home nursing; health and hygiene; recreation in the home; canning and preserving; home carpentering; repairs and maintenance; budgeting; gardening; income tax problems; consumer problems; and hobbies in the home. 9

It would seem that courses of this type could be of very great ralue during the period of readjustment and reorganization of normal living. There have been many shiftings in populations and living conditions have taken on new patterns. There have been many "war marriagea" and young families who will require understanding assistance through education in order to maintain a steady ideal of the family unit." 
Recreational Opportunities in an Adult Education School. Some

form of social and recreational opportunities should be provided for the adults who are in earnest enough to attend school in the evening and work during the day. A real program of planned social activities is educational. Dr. Philip L. Seman said:

\footnotetext{
"We do not know where education begins and recreation ends, or where recreation bezins and education ends. Good education is recreation, and good recreation is education." 10
}

Adult recreation programs can be planned at intervals to provide relaxation from routine. The program might include:

Social hour: meet your classmates in the gym; meet your nelghbors in the gym; folk-danclag in the gym

Hobby clubs, varlous kinds, suggested by students themselves

Community singing clubs: men's chorus; women's chorus; group singing; talent scouting

Travel tours via projector and screen: take a trip Amateur photography

Picnics and hiking

The principal reason for school interest in recreation activities is their contribution to social integration. We live in a highly complex world, and our people must learn to meet one another in a relaxed and pleasant manner.

8 Education for Family If fe, Nineteenth Yearbook, (Ame rican Association of School Administrators, Washington, D.C.) 1941, p.8

9 Dobatin, Frank Mo, Administration of Adult Education, "Parent Education" (The American Book Company, 1938) pp. 407-412

10 Seman, Philip L., Address, Mid-West Conference Adult Education, (College Camp, Wisconsin, July 5, 1937) 
Does Louisville Need an Elementary and Secondary Program of Adult Education? A study of the possibilities for service through adult education would not be complete without a consideration of the need for such a program. Some important facts relative to this need are revealed through the Sixteenth Census of the United States. The table which follows shows these findings:

$$
\begin{aligned}
& \text { TABIE VII } \\
& \text { Findings of the Sixteenth Census } \\
& \text { of } \\
& \text { The United States, } 1940
\end{aligned}
$$

Total population of Louisville......319,077

Population 25 years and older........196,367

Educational Characteristics of Persons 24 years and older:

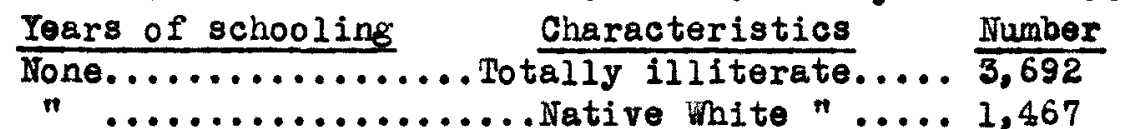

1 to 4 years.........................17,030

1 to 4 years.............Native White.......10,108

7 to 8 years.......................78,165

7 to 8 years........... Native Mhite......66,562

4 years high school..................25,908

4 years college..................... 8,680

Median - school years complete ......8.4

Percent with less than 5 yeers.......10.6

Percent with less than 8 years.......61\%

Percent with less than 12 years......86.8

Percent with less than 16 jears......95.5

11 Sixteenth Census of the United States: "Characteristics of Popalation", Vol. II $\frac{1}{3,1940}$ 
This means that 76,670 native white persons in Iouispillo have completed less than high school entrance reguirements; that 1,467 total illiterates who are native white should be taught to read and write; that 8,641 native white persons have not completed grade 4; that 57,921 native white persons have not completed grade 8; that 40,654 native white persons have not completed grade 12 . The need for adult education service of elenentary and secondary level in Louisville is quite apparent. 


\section{CHAPTER V}

\section{SUMMARY AND CONCLUSIONS}

Adult education is the process of training or guiding adults, who really can learn, so that they may live more abundantly, and enjoy richer and fuller life satisfactions. As a specific movement it is comparably a new phase of education in america, having been developed principally since World War I.

Public schools in general were slow in developing interest in the adult education movement. Howerer, in recent years impetus was gathered throush the assistance of the Federal Government, and today many public school systems have programs for the education of adults which are progressive and extensive. This study reviewed three such urban programs, The Denver Opportunity School; San Jose, California; and Philadelphia, Pennsylvania.

Louisville had night schools for working people as early as 1876, and after 1887 there were fairly continuous attempts made to offer short night school courses during the vinter months. The work in those night schools was largely foundation courses in elementary or vocational education. These schools were well attended. Because of the financial depression of the early 1930's, the Federal Government through the F.F.R.A. and the W.P.A. conducted a program of general adult education for constructive use of leisure 
time, and to direct the thinking of students into purposeful channels. This program was well attended. It served nine years and through it was developed the first accredited Adult Night High School in Louisville.

When the W.P.A. closed and funds were withdrawn, Louisville faced the 1058 of its Adult Education School. in public appeal was made to the Louisville Board of Education to continue the school. This was done for the completion of the term, from April, 1943 until June, 1943. The September following an Adult Wight High School was started at Ahrens Trade School.

The Sixteenth Census of the United States shows that Louisville needs education for her citizens.

In conclusion, it seems that since Louisville is now adult education conscious, as shown through the interest in the continuation of night schools, this is the psychological time to develop a strong and realistic program of adult education which will serve the city effective1y. Such a program should provide teachers for illiterates, classes for pre-high school students, a secondary school course which will develop not onls required subjects for a high school diploma but will also offer courses which will develop understandines of civic, social and world problems, and stimulate interest in further study through university courses of larger understandings; and a vocational course 
which will develop the abilities of all students wo desire to learn skills for earning a living. All of these offerings should be made available to the returning personnel of the armed forces and, in addition, they should have understanding ald through a council established for their benefit. 


\section{APPENDIX}

Who's Who In The Louisville Adult Bducation Program Fecieral Works Projects Administration

Goodman, George H. - Administrator, Horks Projects Administration in Kentucky, July 1, 1935 to June 30, 1943. Born in Paducah, Kentucky; educated in the Paducah Public Schools. Married Margery Evelyn Lockett of Paducah, and has three chilören. Owner and Publisher, Paducah News-jemocrat, 1922-1929. President Paducah Bosra of Trade five years. virector Red Cross Chapter in Paducah; Chairman liccracken County Council of Defense; Liberty loan Drives; hed Cross Drives; Helfare Lrives; Member of Committee that developed Noble Park Playsround (public); liormer member ramily Service Social Security Board; Vice-President, Boy Scout Council. Director Kentucky Bnergency Kelief Haministration 1934-1935. Received Aleernon Sydney Sullivan Award in recognition of his "fine spiritual qualities practically applied to aaily living and his humanitarian endeavors" within the State of Kentucky during 1935.

From July 1, 1935 to June 30, 1943 was State Administrator IPA. Served without compensation from June 1942 to March 1943 as State Director of the Office of Price Administration. In March 1943 became louisville vistrict Director of OPA. Was very much interested in the diult ilucation Program. Said, "I am very proud of the work done under the Aalt Elucation Project; the fine reports that come to my office are Eratifying. I am especially proud of the many persons who have learned to read and write."

Allen, Lindsey E. - State Supervisor and Director of Adult Education Program, Works Projects In Kentucky.

Born in Larue County, Kentucky; attended the rural elementary schools of that county; received his high school eaucation in the High School Department of hestern Kentucky State Teachers College, at Bowling Green, Ky.; B.S. Degree June, 1934 from western Teachers College, and aegree of Master of Arts at the University of Kentucky, July, 1941 .

Harried Christine Stiles, and has two children. Paught in the public schools of Larue County 1921-1929. From July 1, 1930 to June 30, 1934, served as County Superintendent of Larue County schools.

Supervisor and Director of the Kentucky adult Education Program from July 1934 to April 1943.

Now connected with the State Division Vocational Rehabilitation, 
State Department of Education. Said, "Today, it seems reasonable to hope that adult education will be recognized as an integral part of a total prosram of ecucation for all the people."

Harris, Oren A. - Sapervisor Adult Education in Louisville and Jefferson County.

Born in Missouri; educated in the Missouri puolic elementary and high schools; A.B. Degree from Villiam Jewel College, Liberty, Missouri; did post-graduate work at the University of Chicago. Married Stella libe lason of Missouri, and has one child. Taught in the elementary schools of Missouri; served as Fublic School Principal in Webb City, and Lanthrop, inissouri; was Superintendent of Schools at liberty, Missouri; taluht at Springfield Missouri Teachers College, and at Missouri Hesleyan College. Represented John C. Winston, Iyon and Caranhan, and Rand MeNally Fublishing Companies. Supervised adult education and nursery schools in Louisville, Kentucky, both negro and white, 1934 to 1941. Gave course in methods of teaching adults during two summer sessions at Bowling Green, Kentucky, and three summer sessions at the University of Kentucky.

Conducted classes in current events at Louisville City iomans Clab five years; Crescent Hill Womans Club three years; and Shawnee Womans Club two years.

Said, "I believe that every opportunity should be given the adult who wants to advance his or her learning and to better prepare for successful living. Tuition-free schools woula encourage large numbers to attend."

Now connected with the Louisville Hedical Depot in job training of workers.

Horris, Flora l. - Adult Baucation Teacher ana Principal Louisville Adult Education High School.

Born in Louisville, Kentucky; attended Louisville Public Schools; attended ijestern Kentucky State Teachers College, received Standsrd leachers Certificate 1917; began teachine in elementary school at Winth and 0 Streot, Louisville. Married Javid P. Morris, and went to Owen County where Mr. Horris was lounty Agriculture Agent.

Taujht in the Owenton Public Schools three years. Principal Mrapleton Public School, ht. Sterling, Kentucky, four years. Tautht art and public speaking at west liberty High School one year; and in Jefferson County six years.

In 1927 became "faculty wife" at Bastern Teachers College, where Mr. inorris tausht agricultural-economics. Graduated Bastern Teachers College 1932, A.B. Degree, Hajor Bnglish, Minors Social Sciences and Art. Attended University of Chicago 1934. 
Adult Euacation in Louisville February 1935 to June 1943. Assistant Princival Ahrens Adult Night High School 1943-1944. Now, 1944-1945, at Ahrens Adult Night High School. 


\section{BIBLIOGRAPHI}

1 Bryson, Iyman, Adult Education, American Book Company, New York, 1936.

2 Cartwright, Horse A., Ten Years of Adult Education, New York; The Hacmillan Company, 1935 .

3 Dobatin, Frank Mo, Administration of Adult Dducation, New York; The American Book Company, 1938.

4 Englehardt, Fred, Public School Administration, Ginn and Companr, New York, 1931 .

5 Englehardt, and Englehardt, Planning The Community School, New York, 1935.

6 Fisher, Dorothy Canfield, hy Stop Learning, Harcourt Brace and Company, Hew York, 1927.

7 Fisher, Dorothy Canfield, Learn or Perish, "The Kappa Delta P1 Lecture Series", Horace Liveright, New York, 1930.

8 Kotinsky, Ruth, Elementary Education of Adults, American Association of Adul Education", New York, 1941.

9 Martin, Bverett $D_{0}$, The Heaning of a hiberal Education, New York; w. W. Norton and Company, 1926.

10 Rowden, Dorothy, Handbook of Adult Education in the Unitea States, American association of Adult iducation, Revised Edition, 1936.

11 Swift, Fletcher Harper, and Studebaker, John w., What Is This Opportunity School? New York; American Association of Adult Education, 1939.

12 thorndike, Edward L., ana Others, The Fundamentals of Learning, New York: Bureau of Education, 1932.

13 Tolbert, J. Keith, The Establishment of an Adult School, New York, The Kacmillan Company, $19 \overline{36}$.

14 Annual Reports, Board of Trustees The Fublic Schools of Louisville, Year Ending June 30, 1876.

15 Annual Reports, School Boarà of Louisville, Kentucky, 1876-1891. 
16 Alderman, I. R., Bulletin No. 3, United States Bureau of Bducation, 1938.

17 Allen, Lindsey E., lhesis, History of WPA Education Program in Kentucky, University of Kentucky, 1941.

18 Records of the Office of Director of WPA Education in Kentucky, 1940.

19 Hanabook on Education and the Nar, Proceedings of the National Institute on Education and the war, Washington, i. C.: Government Printing office, 1943, 344 pp.

20 National Bducational Association, Research Division, Schools and the 1940 Census, Research Bulletin No. 19: 201-32, November, 1941.

21 Sixteenth Census of the United States, "Characteristics of the Population", Vol. II, Part $\theta$.

22 Pducation for Victory, Official Biweekly of The United States Office of Education, March 20, 1944.

23 Fields, Harold, "Making Education of Adults, Adult", Journal of Adult Education, New York: 12: 40-45, Jan. 1940.

24. Jones, Olga A., Education for Victory, "Soldiers' Attitudes Toward Post-War Education", United States Office of Education, Federal Security Agency, 2:17, Harch, 1944.

25 Libraries and Adult Education: "Report of a Study Made by the American library Association. The Hacmillan Company, 1926.

26 Pennsylvania Program of Adult Education, "Bulletin", Philadelphia, 1943-1944.

27 Community Art Center, Department of Adult Education, San Jose Public Schools, California, 1944.

28 Community Councils in Action, Journal of Adult Education, American Association of Adult Education, New York, 1941

29 Function of Living, Bducation for Victory Journal, July 20, 1944 
30 Education for Family Life, Nineteenth Yearbook, American Assoclation of School Administrators, Washington, D. C., 1941 .

31 Servicemen's Readjustment Act, Bducation for Victory, United States Office of Eacsition, July 20, 1944. 